\title{
NOTE
}

\section{LEGAL AND PRACTICAL ASPECTS OF PETROLEUM PRODUCTS PIPE LINE RATES AND TERMINAL TANKAGE'}

Since the cost of shipping petroleum products by pipe line is substantially less than other overland forms of transportation, ${ }^{2}$ a shipper who utilizes a pipe line to a marketing area not approachable by water can attain a significant competitive advantage over other shippers who use rail or truck, either by reducing his price to customers or by devoting the savings realized thereby to more extensive merchandising. ${ }^{3}$ For this reason, pipe lines have played an increasingly prominent role in the transportation aspect of the oil industry. ${ }^{4}$ Petroleum products pipe lines, with which this Note will be principally concerned, are a comparatively new addition to the scene, ${ }^{5}$ but in 1952 they participated in the transportation of approximately $27.8 \%$ of the year's production of the four products for which products line transportation is ordinarily considered feasible: motor fuel, kerosene, distillate fuel oils (i.e., furnace oils), and liquefied petroleum gases. ${ }^{6}$

1. Much of the information for this Note was obtained through personal interviews with officials and representatives of integrated and independent oil companies, who have requested that their names not be disclosed.

2. For example, the pipe line tariff rate per barrel of gasoline weighing 6.6 pounds per gallon from the vicinity of Philadelphia to the vicinity of Pittsburgh is 22 cents. Keystone Pipe Line Company Local Pipe Line Tariff, Pa. P.U.C. No. 20, effective January 1, 1954. This rate passes on to the shipper the $41 / 2 \%$ Federal excise tax which the pipe line must pay on its gross revenue. By railroad tank car the same service costs $\$ 1.709$, including the $3 \%$ Federal transportation tax. Boin's Freight Tariff No. 68-A, ICC No. A-755, effective July 7, 1942. Item 6020A, Supp. 131, Boin's Freight Tariff No. 90-K, ICC No. A-848, effective December 10,1946 . By tank truck the cost is $\$ 2.107$, including the $3 \%$ Federal transportation tax. Freight Tariff, Pa. P.U.C. No. 19, effective October 10, 1952.

3. See Petroleum Rail Shippers' Ass'n v. Alton \& Southern R.R., 243 I.C.C. $589,628-9$ (1941).

4. For a general discussion of the growth of pipe line transportation and its important place in the oil industry, see Andress, Development of the Pipe Line Industry in Common CARRIER PIPE LINE Operations and Accounting 1 (Graber ed. 1951); Report by Subcommittee on Pipe Line Transportation, Ass'N of AMERICAN RAILROADS 12-4 (May 1, 1944).

5. For a discussion of the spectacular growth of products lines, see de Groot, History and Development of Products Pipe Lines, THE OIL AND Gas Journal 353 (Nov. 10, 1949).

6. The 1952 production of these products totalled $1,840,448,000$ barrels. UNITED States Dept. of tHe Interior, Bureau of Mrnes, Monthly Petroleum StateMENT No. 359, pp. 3, 4, 11 (1953). $511,250,000$ barrels were turned into pipe lines. Id. at 13. This figure represents the total number of barrels which at one time or another were handled by pipe line, and is not limited to products transported solely by pipe line. The number of barrels turned out of pipe lines may vary because of evaporation, expansion, or shrinkage. For example, 866,000 barrels of motor fuel were lost in transit in 1952. Ibid. 
Although some court decisions have raised considerable doubt as to the extent of its application, ${ }^{7}$ Section 1 of the Interstate Commerce Act purports by its terms to include as common carriers all pipe lines engaged in the transportation of oil or products in interstate commerce and to require them to furnish transportation for any shipper upon reasonable request. ${ }^{8}$ However, most products pipe lines, as well as crude lines, are operated by subsidiary corporations owned or controlled by oil companies, or in some cases are owned outright by oil companies. ${ }^{9}$ Historically, shipper-owners have ordinarily constructed products lines in order to get cheap transportation for themselves, and the lines often run directly from shipper-owner refineries. ${ }^{10}$ When regulation of products pipe lines is considered, there is therefore an initial difficulty in the conflict between their essential nature as plant facilities ${ }^{11}$ and the words of the statute which require them to be common carriers. This conflict underlay charges, in the early days of products pipe line growth prior to World War II, that some lines were excluding other shippers in an effort to preserve the benefits of pipe line transportation for their shipper-owners. The lines were accused of establishing prohibitive service requirements, the most widespread being an alleged insistence upon unreasonable minimum tenders, ${ }^{12}$ and of main-

7. See text at note 41 infra.

8. 24 Stat. 379 (1887), as amended, 49 U.S.C. $\$ 1(b), 3(a), 4$ (1946). It provides :

"(1) The provisions of this chapter shall apply to common carriers engaged in-

"...

"(b) The transportation of oil or other commodity, except water and except natural or artificial gas, by pipe line or partly by pipe line. . . .

"...

"(3) (a) The term 'common carrier' as used in this chapter shall include all pipe line companies. . .

". . .

"(4) It shall be the duty of every common carrier subject to this chapter to provide and furnish transportation upon reasonable request therefor. . . "

The Provision as to pipe lines was not included until an amendment in 1906. 34 STAT. 584 (1906).

The Interstate Commerce Act is cited throughout this Note to the original statute at large and to the most recent applicable volume of the United States Code.

9. As of January 1,1938, 96.1\% of "gasoline" (i.e., products) pipe line mileage was concentrated in the hands of sixteen integrated companies. Hearings before the Temporary National Economic Committee pursuant to Pub. Res. No. 113, 75th Cong., 7103 (1939). Although the number of integrated companies owning products pipe lines has since increased, the level of integration has remained substantially the same. It has been estimated that integrated companies now hold $92.2 \%$ of products pipe line mileage. McLean and Haigh, THe Growth of INTEgrated OIL CoMpanies 50 (1954).

10. See Wolbert, American Pipe Lines 48, 111-3 (1952).

11. See Francis, Divorcenent of Pipe Lines 11 (address delivered before Mineral Law Section, American Bar Ass'n, July 16, 1935) ; Mnls, Tre PIPE LINE's Place IN THE OIL INDUSTRY 15-7 (1935); H.R. ReP. No. 2192, 72d Cong., 2d Sess. LxxvII, Part 1 (1933).

12. See Beard, Regulation of Pipe Lines as Common Carriers 94-5 (1941); Cook, Control of the Petroleum Industry by Major OII Companies 39 (TNEC Monograph No. 39, 1941). Complaint, p. 38, United States v. American Petroleum Institute, Civil No. 8524, D.D.C., Sept. 30,1940 . The pipe lines have also been charged with such discriminatory practices as non-ratable taking, that is, preferring 
taining high rates which, since geared by normal competition to rail rates, ${ }^{13}$ bore no relation to cost of operation. ${ }^{14}$ It was further charged that integration resulted in a competitive advantage to shipper-owners, since transportation charges paid by oil companies to subsidiary corporations can be returned in the form of dividends, and those paid to their pipe line departments never leave the corporation..$^{15}$ Although the requirement is dictated by business rather than exclusionary motives, ${ }^{18}$ it has also been stressed that the ordinary pipe line tariff provision requiring all shippers to construct their own terminal tankage may hinder the use of the lines by spot shippers or those with small volumes. ${ }^{17}$

After reviewing the cases decided with regard to the legal status of pipe lines as common carriers, this Note in general will examine the charges noted above only as to common carrier products pipe lines. It contemplates first a comparison of present pipe line rates of return with those of prior years. In this regard, it will consider in particular whether the Consent Decree of $1941,{ }^{18}$ which through limiting dividend payments and credits to parent corporations attempted by indirection to force rate reductions, has made any substantial contribution to the reductions which have actually occurred. Secondly, since any unreasonable service requirements which may have existed seem to have disappeared, ${ }^{19}$ the Note will analyze only the question whether products lines, by failing to provide terminal tankage, are violating any provisions of the Interstate Commerce Act.20

As a preliminary to the discussion, it should be noted that the amendment in 1906 which brought pipe lines within the coverage of the Act ${ }^{21}$ was primarily a remedial measure, designed to combat the monopoly of Standard Oil of New Jersey by forcing its "private carrier" pipe lines to carry oil for others. ${ }^{22}$ On the other hand, the Act in its original form as

the product of the shipper-owner when tenders exceed capacity. See Rostow, A National Policy for the OIL Industry 63 (1948); Comment, 51 Yale L.J. 1338, 1344 (1942). This practice would be clearly illegal under \$3(1) of the Interstate Commerce Act, 24 STAT. 380 (1887), as amended, 49 U.S.C. \$3(1) (1949). It is probably almost non-existent. See Wolbert, AMERICAN PIPE LiNes 41-3 (1952).

13. See Prewitt, The Operation and Regulation of Crude Oil and Gasoline Pipe Lines, 56 Q.J. EcoN. 177, 190 (1942).

14. Id. at 189-93; Comment, 51 YALE L.J. 1338, 1341-2 (1942).

15. The ordinary practice is to charge the sales or marketing department.

16. See text at note 186 infra.

17. See Emerson, Domestic Petroleum Transportation 238 (1947); Prewitt, supra note 13, at 185-6; The Independent Petroleum Co., Hearings before Special Committee Investigating Petroletm Resources pursuant to S. Res. 36, 79th Cong., 2d Sess. 559 (1946); Complaint, p. 38, United States v. American Petroleum Institute, Civil No. 8524, D.D.C., Sept. 30, 1940.

18. United States v. The Atlantic Refining Co., et al., Civil No. 14060, D.D.C., Dec. 23, 1941.

19. See text at note 156 infra.

20. No attempt will be made to examine these charges in relation to the Sherman Act, 15 U.S.C. $\$ 1$, et seq. (1946).

21. 34 Stat. 584 (1906).

22. See In the Matter of Pipe Lines, 24 I.C.C. 1, 3-6 (1912); BEARD, REgUlaTION OF PIPE LINES AS COMMON CARRIERs 11-8 (1941). For a general discussion of Standard Oil's rise to power, see MCLEan aND HaIGH, THE GrowTH OF INTEgrated OIL Companies 58-71 (1954). 
applied to railroads was intended to regulate the practices of carriers which had already dedicated themselves to public use. ${ }^{23}$ A significant example of the difference in regulatory theory between railroads and pipe lines can also be found in the 1920 Amendment, which added Section 1(18) providing that railroads could construct new lines or extensions in interstate commerce only after obtaining a certificate of convenience and necessity from the ICC. ${ }^{24}$ Pipe lines were not included in this provision; ${ }^{25}$ they are therefore forced to be common carriers and have their rates regulated without any grant of monopoly or limited monopoly which would give them a compensatory protection through elimination of competition. Of course common carrier pipe lines receive the privilege of crossing federal public lands, ${ }^{26}$ but this benefit by itself is no quid pro quo for assuming the burdens of common carriage. These variants from the regulatory philosophy of the Act as applied to railroads, together with the particular nature of pipe lines as plant facilities, should be kept in mind when construing the provisions of the Act which govern the operation of pipe lines; it would seem as a general proposition that these factors militate toward a narrow construction.

\section{Status of Pipe Lines as Common Carriers}

In order to fix the context of this Note, it is necessary to establish what incidents of a pipe line's operation may expose it to regulation under the Interstate Commerce Act. A pipe line crossing state boundaries is not necessarily a common carrier under the Act in the sense that under Section 1(4) ${ }^{27}$ it must provide transportation for any shipper upon reasonable request. ${ }^{28}$ An arbitrary imposition of this duty upon an existing carrier which has always been purely private in nature would be a deprivation of due process. ${ }^{29}$ In The Pipe Line Cases, ${ }^{30}$ where the ICC sought to require the defendant pipe lines to file tariffs, it was held that the line owned by the Uncle Sam Oil Company, which carried only the crude oil of its owner from his own wells to his own refinery, was not engaged in transportation

23. See ICC v. Baltimore and Ohio R.R., 145 U.S. 263, 275-6 (1892).

24. 41 StAT. 477 (1920), 49 U.S.C. §1(18) (1946).

25. See Lockin, Economics of Transportation 659 (3d ed. 1947). Motor and water carriers are also required to obtain certificates if they are subject to regulation under the Interstate Commerce Act. 49 STAT. 551 (1935), as amended, 49 U.S.C. $\$ 306$ (Supp. 1952) (motor carriers); 54 STAT. 941 (1940), 49 U.S.C. $\$ 909$ (1946) (water carriers).

26. 41 STAT. 449 (1920), as amended, 49 STAT. 678 (1935), 30 U.S.C. \$185 (1953). Since products lines usually are laid in the vicinity of metropolitan areas, it is doubtful whether they avail themselves of this privilege to any great degree.

27. 24 Stat. 379 (1887), as amended, 49 U.S.C. §1(4) (1946).

28. Cases interpreting the Act have reached the result that a pipe line can be a common carrier under the Act for one purpose, but not for others. See text at note 41 infra.

29. Michigan PUC v. Duke, 266 U.S. 570, 577-8 (1925) (14th Amendment); see Producers Transp. Co. v. Railroad Comm'n of California, 251 U.S. 228, 230 (1920); see Beard, Regulation of Pipe Lines as Common Carriers 28 (1941); RotTschaEFFer, CoNstitutional LAW 497 (1939).

30. 234 U.S. 548 (1914). 
within the meaning of the Act and therefore could not be made a common carrier. ${ }^{31}$ Although the Court did not meet the due process question with regard to the Uncle Sam line, Chief Justice White squarely faced the issue in his concurring opinion. He thought that Uncle Sam was in fact engaged in "transportation," but argued that the Act could not be constitutionally applied to that particular pipe line since it carried only oil produced by its owner. ${ }^{32}$ However, in the same case other integrated defendant pipe lines were directed to file tariffs, the Court saying that since the lines had become common carriers in substance they must also become so in form. ${ }^{33}$ The distinction appeared to be that in the case of those pipe lines, the competitive advantage due to cheaper transportation costs had forced other producers to sell their oil to the integrated producers at the well-head. Although the sales were complete before transportation started, and the lines were technically carrying only the oil of their owners, in effect they were carrying the oil of many other producers and were therefore "carriers in substance." In addition, ultimate control over the entire pipe line system lay in Standard Oil of New Jersey, thereby giving that corporation a virtual monopsony ${ }^{34}$ in crude oil production. The combination of these two factors gave rise to the public interest necessary to justify public regulation. ${ }^{35}$

The Pipe Line Cases of course dealt only with crude lines, and although the general legal principles announced therein can be applied to products lines, the courts have had difficulty in doing so. In United States v. Champlin Refining Co. (Champlin $I$ ), ${ }^{36}$ the pipe line was carrying only its owner's products from his own refinery to his own bulk plant. The Court, emphasizing the language of Section 1(3), ${ }^{37}$ which defines common carriers to include "all pipe lines," sustained the ICC's contention that the owner was required to file valuation data pursuant to a Commission order under the authority of Section $19 \mathrm{a}(\mathrm{g}) .^{38}$ The Court held that Champlin was engaged in "transportation," distinguishing the Uncle Sam situation

31. Id. at 562 .

32. Id. at 563 .

33. Id. at 561 .

34. I.e., a single buyer's market. See Wolbert, AMrrican PIPE Lines 66 (1952). The Court stated that ". . . [Standard Oil] made itself master of the fields without the necessity of owning them and carried across half the continent a great subject of international commerce coming from many owners. . . " The Pipe Line Cases, 234 U.S. 548, 559 (1914).

35. Cf. Munn v. Illinois, 94 U.S. 113 (1876). See Note, 14 Coc. L. Rev. 662, 664 (1914); Comment, 79 Cent. L.J. 19 (1914).

36. 329 U.S. 29 (1946).

37. 24 Star. 379 (1887), as amended, 49 U.S.C. \$1(3) (1946).

38. 37 STAT. 701 (1913), as amended, 49 U.S.C. $\$ 19 \mathrm{a}(\mathrm{g})$ (1946). The Court had sustained the same requirement for a crude oil line in Valvoline Oil Co. v. United States, 308 U.S. 141 (1939). In that case the Court, in interpreting the 1920 amendment to the Act, said that the Act applied to all pipe lines, but the same proposition as in The Pipe Line Cases seemed to be crucial to the decision. That is, Valvoline was buying the oil of thousands of producers at the well-head. Although the case was limited to requiring Valvoline to file valuation data, the company has since filed tariffs. See Wolbert, American Pipe Lines $124 \mathrm{n} .85$ (1952). 
on the ground that since the products were to be immediately marketed, they were not being moved for Champlin's own use. Furthermore, the fact that Champlin used a basing point system in its sales indicated to the Court that buyers were in fact paying for the transportation. However, in a subsequent case (Champlin II), ${ }^{39}$ the Court refused to require Champlin to file tariffs under Section $6,{ }^{40}$ a holding which, combined with Champlin I, thus made the pipe line a common carrier under the Act only for the purpose of filing reports. ${ }^{41}$ This interpretation seems unjustified in the language of the Act. As Mr. Justice Black pointed out in his dissent:

"The Court's holding that Champlin must comply with $\$ 20$ of the Hepburn Act, but need not comply with $\S 6$, cannot be reconciled with clear language in those sections or with our previous decisions construing the same language. Section 20 authorizes the Interstate Commerce Commission to require that 'all common carriers subject to the provisions of this Act' ${ }^{42}$ file, among other things, certain annual reports; $\$ 6$ commands that 'every common carrier subject to the provisions of this Act' 43 shall file schedules of rates with the Commission. I do not understand why it should be necessary to labor the obvious-this language requires Champlin (if it is a 'common carrier subject to the . . . Act') to comply with $\S 6$ if it is required to comply with $\S 20$, or to comply with $\S 20$ if it is required to comply with $\S 6$. The Court holds that Champlin is a 'common carrier subject to' the Act, and accordingly sustains the Commission's order to file reports under $\S 20$. Paradoxically, however, it then proceeds to hold that the same Champlin, though 'subject to' the Act, need not comply with §6. How the Court gives the identical language in the two sections such different meanings is left a mystery." 44

The Court conceded that its position ${ }^{45}$ was inconsistent with the Act's literal terms, but argued that a contrary result would not conform to the

39. United States v. Champlin Refining Co., 341 U.S. 290 (1951).

40. 24 Stat. 380 (1887), as amended, 49 U.S.C. § 6 (1946).

41. In Champlin I the Commission's order was limited to valuation data under \$19. In Champlin II the Commission sought, in addition to requiring Champlin to file tariffs, to require it to file reports under $\$ 20$. Section 20 principally provides for the filing of annual and special reports, such as the annual Form $P$ reports, and requires carriers to install the Commission's Uniform System of Accounts. Champlins II thus supplemented Champlin I with regard to the filing of reports by ordering compliance with $\$ 20$.

42. 34 STAT. 593, now 49 U.S.C. $\$ 20$, which provides that the ICC may require reports "from carriers" and ". . . the term "carrier' means a common carrier subject to this chapter. . .." [Footnote by Black, J.].

43. 34 STAT. 586, now 49 U.S.C. \$6: "Every common carrier subject to the provisions of this chapter shall file. ..." [Footnote by Black, J.].

44. United States v. Champlin Refining Co., 341 U.S. 290, 303-4 (1951) [Footnote by Black, $J_{\text {. }}$ is omitted]. See also Reed, J., dissenting in Champlin $I, 329$ U.S. 29, 39 (1946); Woldert, AMmerican PIPE LINES 126-7 (1952); Note, 37 CORNELI I.Q. 277, 280 (1952).

45. Although this interpretation must be considered the opinion of the Court, since it was contained in the plurality opinion, nevertheless five Justices evidenced in other opinions that they were opposed to it. Id. at 278. 
main purpose of including pipe lines in the Act: the correction of competitive imbalances. ${ }^{46}$ Underlying this argument was probably the fear that forcing Champlin to file tariffs would offend due process, the ground upon which the lower court had rested its decision. ${ }^{47}$ It would seem that this fear was well founded. It is not difficult to find some public interest in products lines, since the products are destined to be sold to the public. Moreover, if the products were originally crude oil bought in the first place from many producers, and if technical form is to be disregarded as in the Pipe Line Cases, there would seem to be no reason for saying that public interest has ceased simply because the oil has been refined. ${ }^{48}$ Nevertheless, the mere fact that customers will buy the products does not by itself give rise to sufficient public interest to warrant regulation; ${ }^{40}$ if it did, regulation could arbitrarily extend even to the price of potatoes charged by corner grocers. If it is coupled, on the other hand, with the fact that the products line enjoys a monopolistic, or potentially monopolistic, power over the transportation into a particular market, there should be no objection, as in The Pipe Line Cases, to application of the Interstate Commerce Act in its entirety. However, it is apparent that Champlin did not meet this test, since it transported and sold only $1.98 \%$ of the gasoline sold in its marketing area, and it appeared that there were an ample number of common carrier pipe lines which independent refiners could use to reach the market.50 Nor, for purposes of calling it a "common carrier in substance," could it be said that the pipe line was carrying the products of others, since it carried only products refined in Champlin's own refinery. The Court's only recourse, therefore, having already committed itself to partial regulation of Champlin in Champlin I, was to take an intermediate position.

Thus in order to fall within the purview of the Interstate Commerce Act, a products pipe line must be engaged in "transportation," but application of the Act is subject to limitations in its purpose and in the Constitution which give birth to the dilemma faced by the Court in Champlin II. It would have been possible, however, to avoid the inconsistent interpretation of the Act to which the Court was driven in that case, if the Court had pursued a different course in earlier cases. If in The Pipe Line Cases the Court had adopted the position of Chief Justice White, it could later have recognized that Champlin was engaged in transportation, but refused

46. United States v. Champlin Refining Co., 341 U.S. 290, 298 (1951). 1950).

47. Champlin Refining Co. v. United States, 95 F. Supp. 170, 175 (W.D. Okla.

48. But it has been argued that Champlin, since it was carrying only its own products, was no different from Uncle Sam. See Comment, 20 TEMPLE L.Q. 592, 594 (1947) ; Comment, 33 VA. L. REV. 212, 213 (1947). (1923).

49. See Wolff Packing Co. v. Court of Industrial Relations, 262 U.S. 522, 536-9

50. See United States v. Champlin Refining Co. (Champlin II), 341 U.S. 290, 299 (1951), citing Champlin Refining Co. Accounts and Reports, 274 I.C.C. 409, 412-3, 415 (1949). But see Whitesell, Recent Federal Regulation of the Petroleum Pipe Line as a Common Carrier, 32 ConNenc L.Q. 337, 349-52 (1947). 
to apply the Act as a whole because of the constitutional objection. ${ }^{51}$ On the other hand, in Champlin I the Court could have denied that Champlin was engaged in transportation, thereby exempting it entirely from the Act. The Court's failure to follow either of these lines of statutory construction has rendered it difficult to determine exactly what standard is to be used for regulation of products lines. Apparently the more immediate public interest in products lines, as compared to crude lines like Uncle Sam, subjects them to Sections 19 and 20 on the theory that publicity of records is an effective, though negative, means of eliminating minor abuses. ${ }^{52}$ However, in the absence of a competitive imbalance, or perhaps sheer bigness, ${ }^{\mathbf{5} 3}$ regulation must stop midway, and products lines which carry only for their shipper-owners need not file tariffs.

The indecisiveness of the holding in Champlin II is illustrated by the most recent development in the Champlin saga: the ICC, probably considering that any possible advantage gained by forcing Champlin to open its records ${ }^{54}$ was outweighed by the administrative cost involved, has since suspended Champlin's obligation to file reports. ${ }^{55}$ Thus the practical result of the Champlin decisions is that although the ICC can theoretically require reports from any pipe line in interstate commerce, today only those pipe lines which file tariffs also file reports. ${ }^{56}$ This step by the Commission would seem to be a wise one, since the principal purpose of financial and valuation reports is to reach a base for rate-making; the need for it largely disappears where the pipe line files no tariffs and has no rates. Moreover, it makes possible a desirable uniformity in administration, since the ICC need no longer deal with hybrids, but can regulate all pipe lines

51. Whether the Court would limit its interpretation to the constitutional application would depend on the intent of Congress in passing the Act. See Stern, Separability and Separability Clauses in the Supreme Court, 51 HARv. L. REv. 76, 82-3 (1937). Since Congress' purpose in including pipe lines in the Act was clearly to combat monpolies, a separable application would seem particularly apt here.

52. Although the prophylactic effect of publicity is doubtful, the Court considered it to be a sufficient basis for the Commission's desire to require reports in Champlin II, United States v. Champlin Refining Co., 341 U.S. 290, 296 (1951); and in Valvoline Oil Co. v. United States, 308 U.S. 141, 146 (1939).

53. See Note, 37 Cornelr L.Q. 277, 279 (1952). Although sheer bigness is probably not the final test of whether a pipe line is subject to $\$ 6$, a court would probably be more likely to detect a public interest and a need to open up competition where huge systems are involved. In 1940, Champlin operated only 516 miles of products trunk lines. 49 I.C.C. Val. Rep. 463, 464 (1942). In contrast, in 1953 Socony-Vacuum and Standard of Indiana, neither of which file tariffs with the ICC, operated 1567 miles and 1722 miles, respectively. ANNuAL DIRECTORY, PIPE LINE News 52, 72 (1953). If the ICC had chosen either of the latter companies for its test case instead of Champlin, the result in Champlin II might possibly have been different.

54. I.e., for purposes of filing valuation and other reports. See note 41 supra.

55. ICC Division 1, Minute of April 20, 1953. Following Champlin II, the ICC had ordered Shell Oil's Products Pipe Line Department to submit valuation data and Socony-Vacuum to install a Uniform System of Accounts. These requirements were also suspended by the same minute.

56. The ICC's Bureau of Accounts, Cost Finding, and Valuation lists no pipe lines which do not also file tariffs. AlpaABetical IIST of Corporate Names of

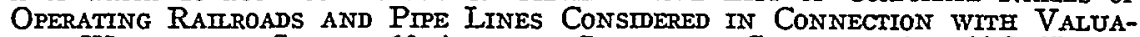
tron Work under Section 19 A of the Interstate Commerce Act 44-8 (Jan. 1, 1954). 
subject to its jurisdiction alike. Finally, it eliminates as a practical matter the questionable judicial gloss imposed on the Interstate Commerce Act by the Court in the Champlin cases.

However, for a variety of reasons most products pipe lines today are operated, either in interstate or intrastate commerce, as common carriers. ${ }^{57}$ Some do so because they feel that the decision in The Pipe Line Cases is applicable to them or because they wish to avoid any possible anti-trust implications which might arise from private operation. Many others, however, do so primarily for the reason that one shipper-owner often cannot provide sufficient volume to make operation profitable. These pipe lines therefore solicit business from additional shippers, and in so doing become common carriers in the true common law sense, since they are holding themselves out for hire. ${ }^{58}$ Moreover, if they have become common carriers the pipe lines can avail themselves of certain privileges which are not granted by the sovereign to private carriers. For example, state statutes often provide that a pipe line may obtain rights of eminent domain only as a common carrier, ${ }^{59}$ and a few reserve to common carriers the right to cross public highways and streams. ${ }^{60}$ Likewise, no pipe line may cross federal public lands without first agreeing to be a common carrier. ${ }^{\text {at }}$ Finally, as to any pipe lines constructed subsequent to the enactment of the Interstate Commerce Act, a dictum by Mr. Justice Holmes in The Pipe Line Cases indicated that there would be no constitutional objection to an interpretation of the Act which would impose common carrier status as a condition upon their operation in interstate commerce:

"So far as the statute contemplates future pipe lines and prescribes the conditions upon which they may be established, there can be no doubt that it is valid." 62

57. In $1949,67.7 \%$ of all products lines were so operated in interstate commerce and reported to the ICC. Petroleum Facts AND Figures 160 (10th Ed. 1952). The balance is made up of those pipe lines which are operated wholly intrastate or which consider themselves purely private carriers. In the same year, $89.2 \%$ of all crude line mileage was operated on an interstate common carrier basis. Ibid.

58. See Washington ex rel. Stimson Lumber Co. v. Kuykendall, 275 U.S. 207, 211 (1927) ; Producers Transp. Co. v. Railroad Comm'n of California, 251 U.S. 228, 231-2 (1920) ; 1 Moore, Law of Carriers 19 (2d ed. 1914) In some cases the pipe lines might be considered contract carriers in the common law sense, rather than common carriers, since their solicitation may be confined to large, steady shippers, and they are therefore not holding themselves out for hire indiscriminately. However, in view of the emphasis placed by the Court in The Pipe Line Cases on carrying the oil of others, it is doubtful whether a pipe line can avoid the status of common carrier under the Interstate Commerce Act once it begins to carry the products of even one shipper other than the shipper-owner.

59. E.g., Texas Civ. Stat. ANN. art. 6022 (Vernon 1949) (crude petroleum pipe lines only).

60. E.g., NEv. Comp. Laws $\$ 4947$ (1929). It would seem that the effect of such a provision is to impose a common carrier status on all pipe lines, since it is impossible to build a pipe line of any size without crossing a highway or stream. This fact raises doubts as to the constitutionality of such statutes. If common carrier status cannot arbitrarily be imposed directly (see note 66 infra), this indirect method seems equally unjustifiable.

61. 41 Stat. 449 (1920), as amended, 49 Stat. 678 (1935), 30 U.S.C. \$185 (1946)

62. The Pipe Line Cases, 234 U.S. 548, 561 (1914). 
It is questionable, however, whether Mr. Justice Holmes intended this remark to apply to pipe lines, unlike those in that case, which are not already common carriers in substance or in which there is no public interest. $^{63}$ No attempt has been made to apply the Act in such a manner where the issue involved filing tariffs. ${ }^{64}$ Although several states have statutes explicitly imposing such a condition on intrastate pipe lines, ${ }^{65}$ their constitutionality is unsettled. ${ }^{66}$

\section{Decline of Pipe Line Rates}

Factors Contributing to Rate Reductions. During the last fifteen years there has been a marked reduction in pipe line rates. This trend cannot be attributed to one single factor; more likely it has resulted from the stimuli of several forces. ${ }^{67}$ First, the ICC has promulgated several orders which established important precedents for affirmative regulation in the future. ${ }^{68}$ Second, competition among the pipe lines themselves and from water and truck transportation has become more severe. ${ }^{69}$ Third,

63. The distinction between future pipe lines and those already in existence at the time of enactment of the Act has been called "more fancied than real." WoLBERT, AMIERICAN PIPE LINES 129 n.111 (1952).

64. The Champlin line was built after the Act, and in Champlin I, where the issue was only as to filing reports, the district court expressly approved Mr. Justice Holmes' dictum. Champlin Refining Co. v. United States, 59 F. Supp. 978, 982 (W.D. Okla. 1945). However, in Champlin II, where the issue was as to filing tariffs, the same district court held that to require Champlin to file would be unconstitutiona1. Champlin Refining Co. v. United States, 95 F. Supp. 170, 175 (W.D. Okla. 1950). (1950).

65. E.g., ARK. Stat. ANN. \$73-1901 (1947); LA. Rev. Stat. tit. 45, §252

66. The Oklahoma Statute was upheld in Pierce Oil Corp. v. Phoenix Refining Co., 259 U.S. 125 (1922). In that case, however, the incorporators, in accordance with the statutory provisions, had voluntarily applied for the privilege of building a pipe line and had been operating for five years prior to the action. The real basis for the decision appears to be that the pipe line had thereby waived any constitutional objections. Cf. Frost \& Frost Trucking Co. v. Railroad Comm'n of California, 271 U.S. 583, 599 (1926), where the Court held unconstitutional a state statute imposing a common carrier status as a condition upon any person desiring to operate an automobile for hire within the state. See Merrill, Unconstitutional Conditions, 77 U. of PA. L. REv. 879 (1929). But see Note, 37 CornerI L.Q. 277, 280-1 (1952). For a good discussion of common carrier status achieved either by voluntary assumption or general business legislation, see BEARD, REGULATION OF PIPE LINES AS COMMON CARRIERS, 28-48 (1941); WOLBERT, AMIERICAN PIPE LiNEs 114-117, 129-131 (1952).

An analogous problem is found in the general rule that a state cannot burden interstate commerce. West y. Kansas Natural Gas Co., 221 U.S. 229 (1911) (state statute prohibiting foreign corporations from building pipe lines across state highways and from transporting natural gas to points outside the state, held unconstitutional); State v. Stanolind Pipe Line Co., 216 Iowa 436, 249 N.W. 366, cert. dentied, 290 U.S. 684 (1933) (state statute imposing tax on pipe line for privilege of doing business within the state, held unconstitutional).

67. The order in which the following factors are placed is in no way intended to be an expression of opinion as to their relative importance. It is only suggested that each one contributed in some part, whether large or small, to rate reductions.

68. E.g., Petroleum Rail Shippers' Ass'n v. Alton \& Southern R.R., 243 I.C.C. 589 (1941); Minnelusa Oil Corp v. Continental Pipe Line Co., 258 I.C.C. 41 (1944); Reduced Pipe Line Rates and Gathering Charges, 272 I.C.C. 375 (1948).

69. See McLean and Haigh, The Growth of Integrated OIL Companies 194 (1954); Wolbert, AMrerican PIPE Lines 16 (1952). 
investigations conducted at regular intervals by congressional committees have thrown the spotlight of publicity on all industry practices. ${ }^{70}$ Fourth, increases in taxes have made high rates undesirable taxwise, since income taxes must be paid both by subsidiary pipe line companies on profits derived from rates received from the shipper-owner, and by the shipperowner on dividends received in return from the pipe line. ${ }^{71}$ Fifth, members of Congress have harassed the industry with the almost annual introduction of bills designed to divorce pipe lines from their shipperowners. ${ }^{72}$ Sixth, improved technology and construction of large diameter lines have reduced the cost of pipe line operation. ${ }^{73}$ Finally, the Justice Department, by instituting remedial actions, ${ }^{74}$ has kept the companies alert to the necessity of using an ounce of prevention in order to avoid a cure by judicial decree which might wreck the economic structure of the entire industry. The most ambitious step taken by the Department in this direction was the "Mother Hubbard" complaint," so-called because it alleged violations of the Sherman Act with regard to almost every aspect of the industry and named 367 defendants, including the American Petroleum Institute. ${ }^{76}$ This ambitious undertaking was instituted in 1940, postponed during World War II, and finally abandoned in 1951, the Government giving as its reason the prohibitive size of the suit.77 In effect it had already been replaced by segment suits, designed to deal separately with some of the specific violations (e.g., exclusive dealing contracts) alleged. ${ }^{78}$

70. E.g., TNEC Hearings, supra note 9; Hearings, supra note 17.

71 . In the case of companies owning $95 \%$ or more of the stock in a pipe line, this double taxation can be minimized by filing a consolidated tax return. INT. REv. CoDE \$141. However, the pipe line must file a consent not to compute its excess profits tax under Section 448 of the Code. Ibid.

72. Since 1940, the following bills relating to pipe line divorcement have been introduced: S. 172, 77th Cong., 1st Sess. (1941); H.R. 1393, 77th Cong., 1st Sess. (1941) ; H.R. 2503, 77th Cong., 1st Sess. (1941); H.R. 1516, 78th Cong., 1st Sess. (1943); H.R. 55, 79th Cong., 1st Sess. (1945); H.R. 6972, 79th Cong., 2d Sess. (1946) ; S. 571, 80th Cong., 1st Sess. (1949) ; S. 3075, 83d Cong., 2d Sess. (1954). In addition, there have been a huge number of bills designed to divorce various segments of the industry from one another. For a full list, see WiLson, PETroLEvM PIPe Line Transportation app. p. 7 (Mimeo. ed., June, 1953, Revision).

73. See McLean and Haigh, The Growth of Integrated OIr. Companies 194 (1954); Stambaugh, Transportation Dynamics 1-2 (address before Div. of Transp., Am. Pet. Inst., Nov. 9, 1953).

74. E.g., United States v. American Petroleum Institute, Civil No. 8524, D.D.C., Sept. 30, 1940 (voluntarily dismissed in 1951); Standard Oil Co. of California v. United States, 337 U.S. 293 (1949).

75. United States v. American Petroleum Institute, Civil No. 8524, D.D.C., Sept. $30,1940$.

76. The nickname may also have been derived from the nursery rhyme, on the theory that the cupboard was bare so far as the Justice Department was concerned. See WOLBERT, AMrerican PIPE Lines 98 n.586 (1952).

77. Department of Justice Press Release, June 6, 1951.

78. So far four such actions have been instituted: Standard Oil of California v. United States, 337 U.S. 293 (1949) (defendants held to have engaged in illegal exclusive dealing contracts); Richfield Oil Corp. v. United States, 343 U.S. 922 (1952) (defendant held to have engaged in illegai exclusive dealing contracts); United States v. Sun Oil Co., Civil No. 10483, E.D. Pa. (1950) (defendant charged with engaging in illegal exclusive dealing contracts; trial set for September, 1954); United States v. Standard Oil of California, et al., Civil No. 11584-c, S.D. Cal. (1950) (seven defendants charged with combining and conspiring to restrain and monopolize trade in the Pacific States area; no trial date set as of February, 1954). 
Another important step was the institution, as a corollary to the "Mother Hubbard" suit, of actions in 1940 against the Great Lakes Pipe Line Company, ${ }^{79}$ Phillips Petroleum Company and Phillips Pipe Line Company, ${ }^{80}$ and Standard Oil Company (Indiana). ${ }^{81}$ The complaints in these actions alleged that the transportation charges paid by shipper-owners and returned by way of dividends or credits were rebates in violation of the Elkins Act, ${ }^{82}$ and demanded that the shipper-owners be ordered to pay to the Government the authorized forfeiture of three times the amount of the alleged rebates. These test cases were, of course, of acute concern to the industry, since the theory, if pursued on an industry-wide basis and applied for the entire period of the statute of limitations, involved a potential liability of some two billion dollars. Negotiations were entered into with the Department of Justice, but there was the initial difficulty that the Department was not so much interested in monetary recovery as it was in accomplishing the divorcement sought in the "Mother Hubbard" suit through the different means of depriving shipper-owners of any return whatsoever. There were prolonged discussions during 1941, and a preliminary draft of a consent decree was drawn up, providing that dividend returns and credits should be limited to $7 \%$. This draft, however, was unsatisfactory to both sides, and an impasse was reached until the advent of Pearl Harbor made it plain that something had to be done. It was clear that the Elkins Act suits were a threat against expansion of the pipe line system during the war and also against the credit of the companies themselves. In order to avoid any disruption of the war effort, therefore, both sides agreed to settle the controversy immediately and accept the proposed draft in unaltered form. On December 23, 1941, twenty oil companies and fifty-nine pipe line companies entered into a consent decree, ${ }^{83}$ the Government agreeing at the same time to suspend the "Mother Hubbard" suit for the duration of the war. Despite its importance in the industry, because

79. United States v. Great Lakes Pipe Line Co., Civil No. 183, D. Del., Sept. 30, 1940.

80. United States v. Phillips Petroleum Co. and Phillips Pipe Line Co., Civil No. 182, D. Del., Sept. 30, 1940.

81. United States v. Standard Oil Co. (Indiana), Civil No. 201, N.D. Ind., Sept. 30, 1940. Citations for all three of these complaints were obtained from WOLBERT, AMrericaN PIPE LINEs 144 n.207, n.208, n.209 (1952). In choosing the particular defendants in these test cases, the Justice Deparment ran the gamut of possible combinations between pipe lines and shipper-owners. The actions included suits against: a company operating a pipe line as a department (Standard of Indiana), a parent corporation and its subsidiary pipe line corporation (Phillips), and a pipe line owned by several shipper-owners (Great Lakes).

82. 32 Stat. 847-8 (1903), as amended, 49 U.S.C. $\$ \$ 41-3$ (1946). Section 41(3) provides:

"(3) Any person ... who shall deliver property for interstate transportation to any common carrier, ... who shall knowingly ... receive or accept from such common carrier any sum of money or any other valuable consideration as a rebate or offset against the regular charges for transportation of such property, . . . shall in addition to any penalty provided by said sections [i.e., sections 41,42 and 43 ] forfeit to the United States... three times the amount ... received. . . "

83. United States v. Atlantic Refining Co., et al., Civil No. 14060, D.D.C., Dec. 23, 1941. 
of the hasty manner in which it was signed the Decree unfortunately was filled with ambiguities ${ }^{84}$ and remains a thoroughly unsatisfactory compromise for all concerned. The companies on the one hand felt that they were being unfairly coerced by the tacit threat of all-out prosecution of the "Mother Hubbard" and Elkins Act suits, and the risks inherent in defending the suits outweighed their confidence in ultimate success. On the other hand, the Department of Justice, which had brought the action on the theory that all dividend and credit returns were unlawful, considered the Decree to be a condonation of illegality.

By the terms of the Decree the defendants agreed that within each year ${ }^{85}$ no dividends or credits could be paid to any shipper-owner in excess of $7 \%$ of its ownership interest in the subsidiary pipe line as valued by the ICC. Earnings in excess of that $7 \%$ were required to be segregated in a surplus account, and these earnings could be used to extinguish certain outstanding debts ${ }^{86}$ or be invested in carrier facilities. However, such facilities could not be included in ICC valuation, nor could any earnings from them be returned to the shipper-owner. A purpose of the Decree was, of course, to force pipe lines to reduce their tariff rates. ${ }^{87}$ It was expected that this goal would be accomplished because pipe lines, in order to avoid accumulating useless capital, would reduce their tariff rates to make the rate of return on their ICC valuations coincide with the dividend limit. It is probable that such a reduction could have been accomplished independently under the influence of the other factors discussed above, or perhaps solely as the result of expanding competition among the pipe lines themselves, but the Decree undoubtedly has contributed to reductions. It also serves as a convenient measuring point for a comparison of past and present pipe line operations, because it was signed at roughly the same time as the occurrence of other important influences (e.g., the decision in Petroleum Rail Shippers' Ass'n v. Alton \& Southern R.R., 88 several divorcement bills, ${ }^{89}$ the TNEC Hearings, ${ }^{90}$ and the institution of the "Mother Hubbard" suit) ${ }^{91}$

84. E.g., the meaning of "earnings, dividends, sums of money or other valuable considerations" upon which the 7\% limit is placed. This wording is contained in Paragraph III of the Decree. For a full discussion of the ambiguities, see WolbERT, AMERICAN PIPE LINES 147-59 (1952).

85. If the pipe line fails to earn $7 \%$ in any year, it may return the difference to the shipper-owner during the following three years in addition to the $7 \%$ permitted in those years. Consent Decree, $\mathbb{T}$ III(d), United States v. Atlantic Refining Co., et al., Civil No. 14060, D.D.C., Dec. 23, 1941. If a pipe line earns 7\%, but fails to return it all, the difference may be returned during any subsequent year in addition to the $7 \%$ permitted in those years, unless such sums have been invested in common carrier facilities and included in valuation as defined by the Consent Decree. Id. at $\Uparrow \operatorname{III}(\mathrm{c})$.

86. I.e., debts contracted prior to entry of the Decree, provided that they were incurred in connection with constructing or acquiring carrier property. Id. at $\mathbb{V}$.

87. See Rostow, A National Policy for the Oil Industry 64-5 (1948).

88. 243 I.C.C. 589 (1941).

89. See note 72 , supra.

90. TNEC Hearings, supra note 9.

91. United States v. American Petroleum Institute, Civil No. 8524, D.D.C., Sept. 30, 1940. 
Irrespective of the cause, the fact remains that pipe line rates, in spite of predictions to the contrary, ${ }^{92}$ have decreased substantially since 1941 and can presently be considered reasonable. ${ }^{93}$ This reduction can be most easily measured for general purposes by following the rates of return (net operating income divided by ICC valuation) ${ }^{94}$ of the individual companies over the years, and it is illustrated by the following table: ${ }^{95}$

\section{Pipe Line Rates of Return 96}

\begin{tabular}{lccccl}
$\begin{array}{l}\text { Company } \\
\text { * Buckeye Pipe Line } \\
\quad \text { Corp. }\end{array}$ & 1938 & 1940 & 1942 97 & 1947 & 1951 \\
& - & - & - & $4.0 \%$ & $4.3 \% \%^{98}$ \\
Buffalo Pipe Line Corp. & $20.5 \%$ & $12.9 \%$ & $3.9 \%$ & $15.2 \%$ & $8.7 \%$ \\
& $(1937)$ & $(1937)$ & $(1937)$ & $(1947)$ & $(1951)$ \\
\hline
\end{tabular}

92. See Wolbert, Amrerican Pipe Lines 159 (1952); Comment, 51 Yale L.J. 1338,1350 (1942).

93. See Wolbert, Amebican PIPe Lines 21 (1952).

94. The valuation figure used is the total of property found by the ICC to be used and owned for carrier purposes plus the amount of property used but not owned. This was the figure used by the ICC in Reduced Pipe Line Rates and Gathering Charges, 243 I.C.C. 115, 148 (1940).

It seems appropriate to use ICC valuation as the base, since it is used both by the Decree for setting the dividend limit and by the ICC for setting rates. See e.g., Petroleum Rail Shippers' Ass'n v. Alton \& Southern R.R., 243 I.C.C. 589, 663 (1941). ICC valuation also seems more realistic, since a pipe line's rate of return should not be regulated according to whether it was built in an inflationary or deflationary period. However, commentators have sometimes used other bases for measuring return. E.g., McLEAN AND HAIGH, THE GROWTH OF INTEGRATED OIL CoArpanies 193 (1954) (borrcwed and invested capital); Wirson, PETroleuns Pipe Line Transportation 133 (Mimeo. ed., June, 1953, Revision) (investment less depreciation).

Although discretion plays a large part in its final determination, the ICC considers, among many others, the following factors in arriving at a valuation: results of corporate operations, original cost, depreciation, cost of reproduction new, and cost of land and its present value. See Loughney, Pipe Line Valuation in ConsMron CARRiER PIPe Line Operations and Accounting 135-6 (Graber ed. 1951). For statements by the ICC as to its valuation methods, see Ajax Pipe Line Corp., 50 I.C.C. Val. Rep. 1, 24-36 (1949); Atlantic Pipe Line Co., 47 I.C.C. Val. Rep. 541, 584-98 (1937).

95. Net operating revenues (after taxes) were obtained from the ICC, StATISTICS OF OIL PIPE LINE COMPANIES for the appropriate year. The valuation years used are the ones most closely preceding the year in question and are set forth in parentheses below the return for each year. In some cases, of course, where there may have been a lapse of several years between the valuation year and the year being examined, this approach will be somwhat unrealistic. The table includes all companies which operated more than 50 miles of product line during the year in question and filed tariffs with the ICC. The study is not limited to those companies which transport only products, since by including those companies which operate crude lines as weil, a broader sampling of the industry is possible. Pipe lines which were never valued, or which filed only valuation reports and no tariffs (e.g., Champlin Refining $\mathrm{C}_{0}$ ), are omitted.

96. A blank space indicates either that the pipe line did not report to the ICC during the year in question; or that, if it did report, it operated less than 50 miles of products lines; or that there was no valuation for the year in question or any prior year.

97. The figures for this year may be somewhat unrealistic, since because of the war pipe lines generally carried only what was allocated to them in directives from the Petroleum Administration for War.

98. Tentative valuation only. The ordinary procedure is for the ICC first to notify the pipe line that its property has been tentatively valued at a given amount. 
Pipe Line Rates of Return 96

Company $1938 \quad 1940 \quad 1942^{\circ}$

$1947 \quad 1951$

Detroit Southern Pipe Line Co. $\begin{array}{ccccl}16.9 \% & 23.3 \% & 6.3 \% & 8.9 \% & 6.7 \% \\ (1934) & (1934) & (1934) & (1947) & (1951) \\ - & - & - & - & 0.0 \% 100\end{array}$

Fairfax Pipe Line Co. Great Lakes Pipe Line Co. $\begin{array}{lllll}33.9 \% & 26.3 \% & 14.8 \% & 7.3 \% & 6.7 \%\end{array}$

Gulf Refining Co. $\begin{array}{lllll}(1934) \quad(1934) & (1934) & (1947) & (1951)\end{array}$

Humble Pipe Line Co.

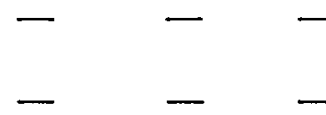

$4.6 \% \quad 4.1 \%$ (1947) (1951)

Keystóne Pipe Line Co.

$21.5 \%$

$21.8 \% \quad 10.9 \%$ $3.2 \%$
$(1947)$ $6.2 \%$ $(1951)$

Magnolia Pipe Line Co.

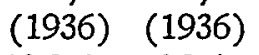

$6.6 \%$

$5.5 \%$

Middlesex Pipe Line Co.

* National Transit Co. $20.9 \% \quad 13.7 \%$ (1947) (1951)

Phillips Petroleum Co.

Phillips Pipe Line Co.

\section{$47.5 \%$} (1939) (1939)

$1.8 \% \quad 17.8 \%^{98}$ (1934) (1934)

Plantation Pipe Line Co.

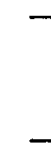

* Project Five Pipe Line Corp.

Pure Transportation Co.

* Salt Lake Pipe Line Co.

Shell Pipe Line Corp.

Sinclair Pipe Line Co.

Sinclair Refining Co.

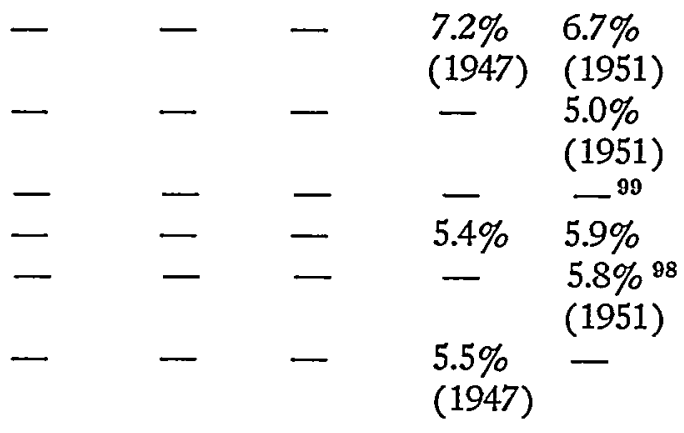

If the pipe line fails to protest within 30 days, the tentative valuation then becomes final. 37 STAT. 701 (1887), as amended, 49 U.S.C. 19a(h) (1946). See e.g., Cover Page, I.C.C. VAL. Docket No. 1343 (Plantation Pipe Line Co., Tentative Val. Rep. 1951).

99. Unable to obtain valuation.

100. Deficit for the year. Since deficits are carried at zero, the average shown for the years in which deficits have occurred is somewhat higher than the average would be if a minus figure were used. 
Pipe Line Rates of Return 96

$\begin{array}{lcclll}\text { Company } & 1938 & 1940 & 1942^{97} & 1947 & 1951 \\ \text { Southeastern Pipe Line Co. } & - & - & - & 7.1 \% & 6.3 \% \\ \text { Sun Oil Line Co. } & 46.5 \% & 20.7 \% & 15.2 \% & 9.3 \% & - \\ & (1934) & (1934) & (1934) & (1934) & \\ \text { Sun Pipe Line, Inc. } & 27.2 \% & 19.0 \% & 8.4 \% & 3.0 \% & - \\ & (1934) & (1934) & (1934) & (1934) & \end{array}$

* Sunray Pipe Line Co. - - - - -

(1951)

Susquehanna Pipe

Line Co.

$17.8 \% \quad 13.2 \% \quad 0.0 \%{ }^{100}$

$5.3 \% \quad 1.3 \%$

(1934) (1934)

(1947)

(1951)

Texas Pipe Line Co.

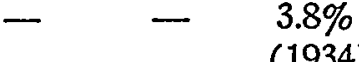

$2.1 \% \quad 7.5 \%$

* Triangle Pipe Line Co.

Tuscarora Oil Co., Ltd.

$15.3 \%$

$12.4 \%$

(1934)

(1947)

$(1951)$

Wyco Pipe Line Co.

(1934) (1934)

$4.0 \% \quad 5.1 \%$

(1947)

(1951)

$6.4 \%$

(1951)

Average ${ }^{101}$

$24.37 \% 20.71 \%$

$10.45 \%$

$6.17 \%$

$7.4 \%{ }^{88}$

(1951)

* Pipe lines not subject to Consent Decree.

It has also been argued that rates would have been reduced in any event through the interplay of free competition among the pipe lines themselves and other forms of transportation. There is merit in this contention, since the principal competition in the industry is among the integrated companies, ${ }^{102}$ and lower transportation costs are obviously a potent competitive weapon. In addition, the table above and other analyses of pipe line rates of return show a general trend as early as 1937 toward substantially reduced rates. ${ }^{103}$ The intervention of government regulation has made it impossible to determine the validity of the argument. However, it would seem that rates probably would not have continued to drop as

101. These averages are somewhat unrealistic, since they make no allowance for the varying size of the companies concerned. In addition, no effort was made to segregate in the averages the companies not subject to the Decree, since such companies constitute only a small segment, and there appear to be no substantial variations in rate trends on the basis of this factor.

102. It has been estimated that the major integrated companies control $80 \%$ of products marketing. Cookenboo, Structure of the Oil Industry 1929-1948 in READINGS IN THE PeTroleum INDUSTRy 72, 91 (Brown ed. 1950). However, this estimation was admittedly based on old data. Id. at 90 . It therefore may not represent the true picture in today's market.

103. When depreciated investment is used as the base, pipe line rates of return show a decrease from $28.39 \%$ in 1937 to $21.42 \%$ in 1940 . LOCKLIN, Economics of Transportation 655 (3d ed. 1947). When borrowed and invested capital is used as a base, there is a decrease from $25.02 \%$ in 1937 to $14.51 \%$ in 1940 . MCLEAN and Hatgh, The Growth of Integrated Oin Companies 193 (1954). 
sharply as they did after 1940 without the impetus of some stimulus other than competition alone. ${ }^{104}$

ICC Regulation. The probability that rate levels would have continued to fall as the result of normal regulation by the ICC is indicated by a Commission decision earlier in the same year that the Consent Decree was signed. In Petroleum Rail Shippers'Ass'n v. Alton \& Southern R.R., ${ }^{105}$ the ICC ordered a reduction in rates for the Great Lakes Pipe Line Company and the Phillips Petroleum Company, operators of what were then the two largest common carrier products pipe line systems in the United States. ${ }^{103}$ The reduction was calculated so as to limit the companies to a return of $10 \%$ based on ICC final valuation. ${ }^{107}$ This figure was, of course, binding only on the defendants in that case, and for that reason it would be unfair to say that other pipe lines would of necessity have reduced their own rates in consequence of the decision and regardless of the other factors discussed above. Nevertheless, the mere fact that the Commission had committed itself in one case would tend to compel pipe lines to acquiesce in demands by shippers for similar reductions, and the Alton case might have foreshadowed extensive regulation by the ICC which, in view of subsequent developments in the industry, might have enforced a policy calling for lower products line rates.

The basis for allowing such a comparatively high return in the Alton case was the contention by the defendants that operation of a products pipe line was a perilous venture. They supported this view with evidence of fierce competition by water carriers and argued that exhaustion or shifting of crude oil fields, especially to areas near their destination terminals, might cause abandonment of refineries near their intake terminals. ${ }^{108}$ However, except in the case of those refineries which were installed on the Gulf coast in order to take advantage of cheap transportation by tanker to east coast markets, refineries are ordinarily placed close to the large marketing areas. ${ }^{109}$ This latter choice of location shortens the more expensive products haul ${ }^{110}$ and eliminates the possibility of having to move

104. Compare Wolbert, American PIPe Lines 21-2 (1952).

105. 243 I.C.C. 589,665 (1941).

106. In 1941, Great Lakes operated 2,073 miles of products trunk line, and Phillips operated 1,075 miles. ICC, Statistics of OIL PIPE Line Conipanies 6 (1941).

107. Petroleum Rail Shippers' Ass'n v. Alton \& Southern R.R., 243 I.C.C. 589, 663 (1941).

108. Id. at 661-2.

109. This was generally true at the time the Alton case was decided. Id. at 655 . See Statement of Robert E. Wilson, TNEC Hearings, supra note 9 at 8619, 8630-1 (1939). However, there has been a modern-day tendency to build refineries closer to the source of supply. The choice is often dictated by the market for heavy fuels near the field. Since pumping costs are higher for heavy fuels, if a market can be found near the field the company may decide to locate its refinery there. If not, it will be located near a marketing area. Moreover, with the discovery of new fields, for example those in the Dakotas and Wyoming, it is becoming possible to locate refineries so that they are simultaneously close to both field and market.

110. The cost of transporting crude oil runs between 2.0 and 4.0 cents per barrel per 100 miles, whereas the cost of transporting products runs between 3.5 
when a particular field is exhausted. In addition, refineries were historically hazardous themselves, since they were often constructed before the establishment of a source of crude oil by some economical form of transportation. Today, however, the usual practice is to build only after such hazards have been eliminated and there is an assured means of cheap transportation to the refinery. Perhaps for these reasons, the fears expressed by the defendants in the Alton case have not materialized, and products pipe line mileage increased from 8539 miles in $1940^{111}$ to an estimated 24,000 miles in $1952 .{ }^{112}$ It can be inferred from these figures that the higher return allowed to products lines is no longer justified by their relative newness and the unpredictability of their success, and that the ICC might today order their rates lowered, perhaps to coincide with the $8 \%$ return allowed to crude lines in Reduced Pipe Line Rates and Gathering Charges. ${ }^{113}$ In fact, it would seem that the prospects of a products line, since it usually begins at or near a refinery, are less uncertain than those of a crude line, which becomes useless when the field it serves is depleted. On the other hand, products lines are carrying commodities which will be marketed almost immediately to the general public, and the size of its throughput therefore depends in great degree upon the ability of its shippers to hold their markets. Selling to the public is a delicate matter and requires skill in the proper utilization of, among other things, attractive selling facilities (e.g., service stations), effective advertising, trained sales personnel, and even psychologists and marketing research experts. Small mistakes in technique by the shipper cause him to lose customers, and the pipe line suffers a corresponding loss when he curtails his shipments. This phenomenon is probably not of great importance where the pipe line's throughput is supplied by large, steady shippers with relatively stable demands and astute marketing departments. Nor would it cause any concern to a huge pipe line system which can

and 5.5 cents per barrel per 100 miles. Wilson, Petroleum Pipe Line TransportaTION 70-1 (Mimeo. ed., June, 1953 Revision). The fact that some crude oil is lost during the process of refining makes the cost per barrel of transporting crude oil slightly more expensive when that factor is considered. However, the loss is too small (usually about $3 \%$ or $4 \%$ ) to be significant.

111. The Petroleun Data Book H-5 (2d ed. 1948). This figure includes both those companies reporting to the ICC and those not reporting. In 1940, a total of 5772 miles of products pipe line were reported to the ICC. ICC, STATISTICS of Oil Pipe Line Companies 6 (1940).

112. 31 Plate's Otlgram No. 74 (Apr. 16, 1953). This figure also includes both those companies reporting to the ICC and those not reporting. In 1952 a total of 19,305 miles of products pipe line were reported to the ICC. ICC, STATISTICS OF OIL PIPE LINE COMPANIES 8 (1952). Figures which include the factors of increases in pipe line diameters and business as well as increases in mileage are also illustrative. In 1940, products lines carried 23,740,946,000 barrel-miles of refined oils. ICC, Statistics of PIPE LINe Companies 7 (1940). By 1952, the figure had increased to $142,425,912,000$, or roughly six times as much. ICC, Statistics of Orl Pipe line Conrpanies 11 (1952).

113. 243 I.C.C. 115, 143-4 (1940). Only an order to show cause why the rates should not be reduced stemmed from this case. However, the defendants reduced their rates, and in 1948 the rates were found to be lawful in accordance with the standard set forth in the original case by the ICC. Reduced Pipe Line Rates and Gathering Charges, 272 I.C.C. 375, 384 (1948). 
absorb losses elsewhere. If, however, a single products line with only one market is at all dependent upon small shippers, the instability of their demand, caused by their lack of a widely known brand name and the possible inroads of competitive advertising, is an important factor to be considered in estimating the prospective profits of the pipe line.

Since conditions vary in different localities, it is impossible to predict what the Commission would today consider to be a fair return for an individual products pipe line, but it seems clear that both crude and products lines are a sufficiently hazardous undertaking to warrant a return in excess of that ordinarily allowed to typical utilities. ${ }^{114}$ Both types of oil lines become almost obsolete if a competing line with larger diameter and consequently greater throughput and lower rates is constructed; both depend ultimately upon a wasting asset; and both represent a huge investment which must be abandoned in the ground if it proves unprofitable. ${ }^{115}$

Pipe Line Divorcement by Elimination of Dividends and Credits. Despite its probable contribution to rate reductions, the Consent Decree has been criticized as ineffectual because shipper-owners still maintain a competitive advantage over other shippers to the extent that their transportation expenses are reduced by receiving the authorized $7 \%$ return from their pipe lines.116 From a purely economic viewpoint this criticism has no validity, provided that the return to the shipper-owner is a reasonable one. So long as the shipper-owner has capital to invest, he will almost certainly realize a return which he can use to defray transportation expenses. In this respect it is immaterial whether the capital is devoted to a pipe line or any other investment. However, if it is considered undesirable for a shipper to earn a return on a carrier by which he transports his own commodities, a possible solution would be to prohibit the return of any dividends or credits from the pipe line. ${ }^{117}$ This step would in effect accomplish pipe line divorcement, ${ }^{118}$ since it would remove the incentive on the part of shipper-owners to retain their pipe lines for a protracted length of time or to build new pipe lines in the future. It would seem that no oil company would risk the huge capital investment in such a hazardous enterprise, knowing that the advantages of pipe line transportation must be shared with competitors and that no profit could be realized. ${ }^{119}$

114. The rates of return set in the past by different commissions for typical utilties have varied between $45 \% 2 \%$ (based on prudent investment) and $6 \%$ (based on fair value). The latter figure is frequently adopted. See Rose, The Bell Telephone System Rate Cases, 37 VA. I. ReV. 699, 718 (1951).

115. For a discussion of the specialized character and hazards of pipe lines, see Mclean and Haige, The Growth of Integrated OIL Companies 190-1 (1954).

116. Rostow, A National Policy for the OIL Industry 63 (1948); Comment, 51 Yale L.J. 1338, 1351 (1942) ; Comment, 9 U. of ChI. L. Lev. 503, 504 (1942).

117. This plan was originally suggested by the Justice Department at initial negotiations with regard to framing the Consent Decree. See text at note 82 et seq. supra.

118. Cf. Black, Oil Pipe Line Divorcement by Litigation and Legislation, 25 CoRNELL L.Q. 510, 514-23 (1940).

119. However, it is possible that the oil companies would build lines despite the fact that they must be shared with others, on the theory that the lower trans- 
The only alternative would be to construct private lines, but in view of the fact that single shipper-owners often cannot support a pipe line alone, ${ }^{120}$ and in view of the indications in decided cases that size may be relevant in impressing common carrier status, ${ }^{121}$ it is doubtful whether such an attempt would be successful except for small spur lines.

However, the Consent Decree in its present form is a bar to abolition of dividends and credits under the Elkins Act, since the Decree clearly states that a 7\% return is permissible under the Act.122 A consent decree cannot be modified without consent of the parties unless there has been a significant change of circumstances, ${ }^{123}$ and it would certainly seem that the oil companies would never consent to a modification prohibiting any return whatsoever. The fact that products lines have become somewhat less hazardous ${ }^{124}$ does not appear to be a sufficient change of circumstances to justify denying a return to their shipper-owners, and the decline in rates since 1940 is a change which is favorable to the industry rather than the Justice Department. The suggested remedy ${ }^{125}$ would therefore have to be accomplished by means of legislative action. ${ }^{126}$ The constitutionality of such action finds support in the Interstate Commerce Act's commodities clause, which declares it to be unlawful for any railroad to carry certain commodities in which the railroad has an interest. ${ }^{127}$ The constitutionality of the commodities clause was sustained in United States v. Delaware \& Hudson Co., ${ }^{128}$ and in a later case ${ }^{129}$ the Court ordered divorcement of certain subsidiary coal companies and parent railroad companies because the railroads, by carrying the subsidiaries' coal, were violating the clause. Since immediate divorcement of pipe lines by legislation would therefore probably be constitutionally unobjectionable, this indirect

portation costs would allow the entire oil industry to significantly undercut competing industries such as coal. In addition, if the demand for gasoline in a marketing area is elastic, the demand in the area would increase if gasoline were sold at a cheaper price because of lower transportation costs. The large oil companies might wish to take advantage of this increased volume, even though it must be shared with competitors.

120. See text at note 58 supra.

121. See text at note 53 supra.

122. Consent Decree, IIIII, United States v. Atlantic Refining Co., et al., Civil No. 14060, D.D.C., Dec. 23, 1941.

123. United States v. Swift \& Co., 286 U.S. 106 (1932); United States v. Radio Corporation of America, 46 F. Supp. 654 (D. Del. 1942).

124. See text at note 112 silpra.

125. The remedy could be also accomplished by a Sherman Act prosecution, the merits of which are beyond the scope of this Note.

126. However, prohibition of dividend payments by a subsidiary to its parent has been ordered as an incident to dissolution under the Sherman Act. Standard Oil Co. v. United States, 221 U.S. 1, 79 (1910).

127. 34 STAт. 585 (1906), as amended, 49 U.S.C. $\$ 1(8)$ (1946). It provides:

"It shall be unlawful for any railroad company to transport . . . any article or commodity, other than timber and the manufactured products thereof, ... in which it may have any interest. ..."

128. 213 U.S. 366, 415 (1909).

129. United States v. Reading Co., 253 U.S. 26, 62 (1920). 
method of dividend and credit prohibition would seem permissible. ${ }^{130}$ In general, however, if divorcement were necessary it would appear more desirable that Congress should order it in explicit terms. It would be inconsistent to achieve it by indirection when Congress has repeatedly, during the last half century, refused to sanction it by express legislation.131

Aside from the legal validity of prohibiting all dividends and credits to shipper-owners, it would seem inadvisable from a practical viewpoint. It would tend to force integrated pipe lines to operate at cost in order to avoid the accumulation of useless capital, ${ }^{132}$ and unless shipper-owners decided to sell their interests, the short-range result would therefore be an increase in competition from independent shippers and a somewhat lower price to consumers. However, the rate reductions of integrated lines would have to be met by competing methods of transportation, which would thus have their profits reduced. It may be necessary in some cases to make reasonable regulations of rates which incidentally affect unregulated competitors. However, in this case it would seem far more desirable, since the ultimate goal would be divorcement, to order it directly instead of using an indirect method which would eliminate the profits of innocent businessmen so long as the oil companies retain ownership of the lines. In the case of those competitors already operating at a narrow margin, the regulation considered here would be destructive. On the other hand, if the shipper-owners later decide to sell out, most likely by simply distributing their pipe line stock to their own shareholders, the immediate effect probably would be an increase in pipe line rates by the independent operators to the maximum point that the traffic and the ICC would allow. Any advantage gained by the consumer in the interim would therefore be lost. In fact, the consumer might in the long run lose more than he has gained; there would no longer be any possibility that the integrated companies would use low transportation charges as a means of competing among themselves.

The merits and demerits of divorcement have been widely discussed ${ }^{133}$ and are largely beyond the scope of this Note. Advocates of divorcement

130. But cf. Smyth v. Ames, 169 U.S. 466, 526 (1897). In that case, the Court held that a carrier could not constitutionally be deprived of a fair return. Since the suit was brought by a shareholder of the carrier, it would seem implicit in the holding that the return was for the shareholder's benefit and that he could not constitutionally be deprived of it.

131. See note 72 supra.

132. The sharp decline in rates subsequent to the Consent Decree illustrates the fact that most pipe lines were unwilling to accumulate useless surplus. However, it is doubtful whether they would drive rates all the way down to cost, since some cushion of surplus must be maintained to guard against future losses. In addition, holding rates somewhat higher than cost might benefit the shipper-owner by preventing new competition from shippers operating at a narrow margin. Compare Comment, 51 YaLE L.J. 1338, 1350 (1942).

133. E.g., Mills, The Pipe Line's Place IN THE OIL INDUSTRY c. 5 (1935); WOLBERT, AMERICAN PIPE LINES 100-104 (1952); Rostow and Sachs, Entry into the Oil Refinery Business: Vertical Integration Re-examined, 61 Y ALE L.J. 856, 895-900 (1952) ; Comment, 51 YaLE L.J. 1338, 1353-6 (1942). Cf. Cross, Vertical Integration in the Oil Industry, 31 HARv. Bus. REv. No. 4, p. 69 (1954) (divorcement of marketing considered and deemed undesirable). 
ordinarily argue that it would permit entry into the industry of more independent refiners, that pipe line rates would be driven down in order to attract this volume, and that the end result would be lower consumer prices. Opponents, on the other hand, argue that independently owned pipe lines would be reluctant to enter new fields, thereby deterring "wildcatting" 134 activities and withholding sources of crude oil supply from refiners. They also contend that because of the hazards involved, the loss of cost advantages in integration, and the tendency on the part of independent pipe lines to charge the maximum possible rates, pipe line rates would in fact increase. However, one argument sometimes made by divorcement opponents deserves mention in more detail: the probable inability of independently owned pipe lines to borrow the capital necessary to make the additions which will be required by future growth of the oil industry. Huge sums of money are needed. For example, Oklahoma Mississippi River Products Line, Inc. presently contemplates spending $\$ 19,350,000$ on the construction of a 475 mile line (partly twelve inch diameter and partly ten inch) from Duncan, Oklahoma, to West Memphis, Arkansas. ${ }^{185}$

Like any other business, a pipe line has many costs which vary with volume. Most of the line's operating expenses, however, are fixed costs, ${ }^{136}$ and the paramount obstacle to financial success is the necessity of maintaining throughput and rates at a level high enough to provide income above fixed costs. A company wishing to construct a pipe line must therefore be able to show a prospective lender of capital that the line has an assurance of sufficiently large volume, at rates which shippers will be willing to pay. Integrated companies have no difficulty in this regard, since the parent oil company's stock ownership is in effect a guarantee that it will use the pipe line to protect its investment. ${ }^{137}$ Independent pipe lines, on the other hand, would have no such guarantee, and for that reason the large lenders and investors such as banks and insurance companies would be reluctant, and possibly unable under laws regulating their investments, ${ }^{138}$ to risk the capital. If the pipe line were to borrow money

134. I.e., prospecting and drilling new wells in territory not known to be productive. RAILROAD COMMITTEe FOR THE STUDY OF TRANSPORTATION 57838-192 (Group 7 Report-Petroleum, Sept. 12, 1945).

135. This figure includes all costs incidental to the construction (e.g., pumping stations, engineering, interest during construction). Prospectus, OKLAHOMA MISSISSIPPI RIVER PRODUCTS LINE, INC. 5 (1953). See also the estimated costs listed in McLean and Haigh, The Growth of Integrated OIL Companies 188 (1954).

136. It has been estimated that a pipe line's fixed expenses range between sixty and seventy per cent of its total expenses. Emerson, Salient Characteristics of Petroleum Pipe Line Transportation, 26 LAND EcoN. 27, 31 (1950).

137. The shipper-owner will sometimes formally agree to supply a certain amount of volume. E.g., Prospectus, OkLahoma Mississippi RIver Products Line, Inc. 10 (1953) (throughput agreement with shipper-owner Sunray Oil Corporation).

138. For example, in Pennsylvania savings banks not under special charter are very strictly limited in their investments. PA. STAT. ANN. tit. 7 \$ 819-1208 (Purdon 1939), as amended, tit. 7, $\$ \$ 819-1208$ (Purdon Supp. 1953). 
in the "risk money" market, it would have to agree to a high return and a quick pay-back, a condition which, under present ICC decisions limiting pipe line rates of return, it would be unable to fulfill.

An illustration of the inability of independent pipe lines to finance construction was the United States Pipe Line Company. ${ }^{139}$ This company was recently formed for the purpose of building a 1500 mile pipe line, with a capacity of 300,000 barrels per day, from Beaumont, Texas, to Newark, New Jersey, at an estimated cost of $\$ 142,000,000 .^{140}$ However, the project had to be abandoned when it was found that enough capital could not be raised without throughput guarantees from large companies. There is no reason to believe that this difficulty would be alleviated by divorcement. If they had no pipe lines of their own, large oil companies would probably be willing to give informal letters of intent to a company proposing to build one. These letters would indicate that the large oil companies would use the line so long as it remained profitable, but they would never constitute a promise to use the line constantly, despite rate reductions elsewhere. Since in most large marketing areas there is an ever-present threat of competition from water carriers, ${ }^{141}$ these letters would be no inducement to investors.

On the other hand, a few pipe lines have been built without the aid of shipper-owner affiliation. A recent example is the Kaneb Pipe Line Company, which has constructed a 248 mile line in Kansas and Nebraska, ${ }^{142}$ but such a comparatively small operation is no criterion for a conclusion that similar undertakings would be possible on the huge scale necessary in the industry as a whole. ${ }^{143}$ However, it is possible that after divorcement the pipe lines might integrate horizontally and attempt to borrow on the strength of their credit as large, well-established, going concerns. A present-day example is the Buckeye Pipe Line Company, which has recently expanded its vast system to include a products line network in the east. ${ }^{144}$ It did so without the need for throughput guarantees, and apparently was able to borrow capital solely because of its reputation as a successful crude line operator for many years. Thus, new construction might be accomplished despite divorcement. However, where the proposed pipe line is a tremendous venture relative to the size of the existing system, the company wishing to build the line would probably have to prove the efficacy of the project as a business matter, and that showing would often depend upon the existence of throughput guarantees. In addition, there is the possibility that the horizontal integration necessary to weld several

139. Later called American Pipe Line Corp.

140. See The Oil Daily, Oct. 30, 1952, p. 2.

141. See text at note 202 infra.

142. See Pipe Iine News, Annual Drrectory 64 (1953); The Oil Daily, Nov. 2,1953, p. 2 , col. 2 .

143. In addition, it is believed that the line might have had the tacit backing of a group of independent refiners and was therefore in effect a species of integration.

144. See Helmbrecht, Buckeye Builds Northeast Products Line, THE OIL AND Gas Journal 98 (June 8, 1953); The Oil Daily, Oct.23, 1953, p. 2, col. 1. 
pipe lines into a system large enough to ensure investors of its ability to make huge expansions without throughput guarantees might be prevented by the provisions of the Sherman Act ${ }^{145}$ or Section 7 of the Clayton Act, ${ }^{146}$ as integration in restraint of trade.

\section{Terminal Tankage}

The second segment of this Note's examination of common carrier products pipe lines will be concerned with the legal and practical questions involved in the necessity that all shippers construct their own terminal tankage. Since large shippers ordinarily have already built tankage for themselves, discussion will be principally leveled at the question of whether pipe lines are required by the terms of the Interstate Commerce Act to provide tanks for small or spot shippers who cannot afford to build their own.

The problem of the small or spot shipper can be illustrated by the hypothetical case of an independent jobber of gasoline who, because he has an opportunity to buy at a low price, wishes to buy directly from an independent refiner in a distant area. If his marketing area is served by a pipe line, his need to use it will depend on the availability of other means of cheap transportation. In general, if the jobber can find water transportation over the entire distance from the refinery, he can ship more cheaply by water than by pipe line if he is making a moderately long haul with large volume. ${ }^{147}$ However, this generalization loses its validity where the water route is considerably more circuitous than the pipe line route, or where it may be necessary to leave the water and resort to overland transportation other than pipe line over a large part of the haul.

The following comparisons illustrate the widening cost differential between pipe line and water transportation, as in each case it becomes less possible for a shipper to find parallel water transportation in competition with a pipe line. For example, if the jobber markets in Pittsburgh, and the refinery is located in the Beaumont-Port Arthur area of Texas, he can ship his gasoline by river tow up the Mississippi and Ohio Rivers for approximately $64.9^{148}$ cents per barrel. On the other hand, one using the Gulf and Project Five pipe lines can ship to Helena, Arkansas, and make

145. 15 U.S.C. $\$ 1$, et seq. (1946).

146. 15 U.S.C. $\$ 18$ (1946).

147. The most expensive form of transportation, considering only the line haul type of movement over distances to which the method is adopted, is by railroad. Then follow, in the order of most expensive to least: truck, barge, products pipe line, crude oil pipe line, river tow, and tanker. WILson, PETROLEuM PIPE IINE Transportation 68 (Mimeo. ed., June, 1953 Revision). Cf. Emerson, Tae Place of the TANker in the Transportation of ENERgy table 3, p. 8 (Paper presented to the Cent. Comm. on Transp. by Water, 32d Ann. Meeting of Am. Pet. Inst., Nov. 11, 1952).

148. This cost is computed at 2.25 mills per ton mile. Of course, the charge will vary with the condition of the market and the length of the haul. The gasoline is considered to weigh 6.144 pounds per gallon, or 7.75 barrels per short ton, for purposes of all computations here relating to barge transportation. It is also assumed that the shipment will be of 25,000 barrels or more. If it is less, the charge would be correspondingly higher. 
a short haul up the rivers, the total cost being about $61.5^{149}$ cents per barrel. If, however, the jobber wished to ship only so far as Helena, it would cost him approximately 30.6 cents per barrel ${ }^{150}$ in contrast to the pipe line's tariff rates of 20 cents per barrel over the shorter route. ${ }^{151}$ Likewise, if the jobber markets in Greensboro, North Carolina, and wishes to deal with an independent refiner at Port Arthur, he must ship by tanker to Wilmington, North Carolina, and truck in at a total cost of approximately 97.8 cents per barrel; ${ }^{152}$ in comparison, one using the Bayou and Plantation pipe lines could ship for approximately 53.0 cents per barrel. ${ }^{153}$

149. The rate from Port Arthur to Helena is 20 cents per barrel. Gulf Refining Co. Tariff, I.C.C. No. 134, effective February 4, 1954. Since the haul from Helena to Pittsburgh is shorter than frcm Port Arthur, the barge rate is probably higher than 2.25 mills per ton-mile. For purposes of this comparison, the rate was computed at 2.50 mills per ton-mile. The Gulf tariff includes the cast of loading into barges at Helena. No cost is added into either comparative rate for evaporation loss in transit, since it is believed that it will be about the same for both hauls. ton-mile.

150. Because of the shorter haul, the barge rate is computed at 2.50 mills per

151. Gulf Refining Co. Tariff, I.C.C. No. 134, effective February 4, 1954.

152. The tanker rate from Port Arthur to Wilmington, North Carolina, is 25.9 cents per barrel ( $\$ 2.25$ pet long ton of gasoline weighing 6.14 pounds per gallon), using U.S.M.C. rates. War Shipping Administration, Rate Order No.0432, p. 2 (1946). U.S.M.C. rates are those which were established by the Maritime Commission during World War II for vessels appropriated by the Federal Government for Government service. The industry still uses these rates as a yardstick, measuring going rates in terms of percentages plus or minus the U.S.M.C. rates. For example, as of April 7, 1954, the going rate was U.S.M.C. less $421 / 2 \%$. Tanker rates fluctuate greatly, even from day to day, and therefore no effort was made to compute this hypothetical comparison for any specific day. The evaporation loss in transit, which must ordinarily be borne by the shipper, will in most cases not exceed $1 / 2 \%$, or 125 barrels on a 25,000 barrel shipment. As of March 24, 1954, the tankwagon price posted by Atlantic Refining and Esso Standard at Charlotte, North Carolina, was 16.0 cents per gallon of house brand gasoline. National Petroleum News, March 24, 1954 , p. 56. Using this price, the shipper would lose $\$ 840.00$ worth of gasoline. Spread over his entire 25,000 barrel shipment, this loss would increase his transportation cost per barrel by 3.4 cents. A five cent handling charge at Wilmington is also included.

The truck rate from Wilmington to Greensboro is 63.5 cents per barrel (22.9 cents per 100 pounds). This rate is for several different petroleum products, at an average weight of 6.6 pounds per gallon. Supplement No. 13 to N.C.U.C. No. 40, effective January 8,1954 . No cost is included for evaporation loss, since the loss for this short haul by truck would probably be negligible. However, any loss that occurs must be borne by the shipper.

153. The pipe line rate from Port Arthur to Baton Rouge is 9 cents, using the Bayou Pipe Line System. Keystone Pipe Line Co. Tariff, I.C.C. No. 39, effective January 1, 1954. The Bayou Line is jointly owned by several companies (Keystone, Crown Central, Fairfax, Shell, and Pure), and the rate may vary according to which tariff is used.

The rate from Baton Rouge to Greensboro is 39 cents. Plantation Pipe Iine Co. Tariff, I.C.C. No. 16, effective January 1, 1954.

Keystone has a $1 / 2 \%$ deduction for evaporation loss and Plantation a $1 / 4 \%$ deduction. On a 25,000 barrel shipment, this loss would amount to 187 barrels, or 7,854 gallons. Using the tankwagon price at Charlotte of 16.0 cents per gallon, the shipper would lose $\$ 1256.64$. Spread over his entire 25,000 barrel shipment, this loss would increase his transportation cost per barrel by 5.0 cents.

In many cases, of course, it is impossible to find pipe line transportation to precisely the market that a shipper wishes. In that case, if there is competing water transportation over much of the haul, using the pipe line route may be more expensive. For example, it has been estimated that from Houston, Texas, to Lynchburg, Virginia, the cost using pipe line transportation principally is $\$ 1.117$ per barrel, whereas the cost using tanker transportation principally is $\$ 1.050$ per barrel. McLean and Haigh, The Growth of Integrated OtL Companies 184 (1954). 
It is apparent, therefore, that in many cases the jobber must use the pipe line in order to maintain his competitive position, ${ }^{154}$ and it has been charged in the past that the pipe lines have imposed unduly stringent service requirements, such as high minimum tenders, ${ }^{155}$ in order to preserve the line for shipper-owners.

Any unreasonable service requirements which may have existed seem to have been generally mitigated or eliminated, in concert with the reduction of rates. For example, the principal service requirement ordinarily complained of is the minimum tender insisted upon by all pipe lines. ${ }^{156}$ Products pipe lines rightly justify this requirement, 50,000 barrels being alleged as typical in 1939,157 on the ground that it is necessary to preserve the identity of the shipper's product by preventing commingling between products as they pass through the line. Of course, the size of the requirement will vary according to the diameter and length of the pipe, ${ }^{158}$ but in the Alton case ${ }^{158}$ the Commission sustained a 25,000 barrel requirement for both Phillips and Great Lakes, and most pipe lines today have similar requirements. ${ }^{160}$ In addition, many lines also allow a smaller tender subject to delay in shipment until the full tender is accumulated from other shippers with the same type and grade product. ${ }^{101}$

However, one important obstacle to the small or spot shipper's use of a pipe line remains: the necessity that he construct his own terminal tankage. Any shipper desiring to transport his products by a particular

154. Although these rate comparisons are based on real figures, they are intended only to illustrate cost differentials and not to reflect in any way on the pipe line companies named. For example, Plantation undertakes to provide terminal tankage for all shippers at point of origin. Plantation Pipe Line Company Tariff, I.C.C. No. 16, effective January 1, 1954.

155. See note 12 supra.

156. For an excellent discussion of the entire problem of minimum tenders, see Wolbert, AMerican Pipe Lines 22-36 (1952).

157. Cook, Control of the Petroleum Industry by Major Oil Companies 39 (TNEC Monograph No. 39, 1941).

158. Contamination ordinarily varies according to the length and diameter of the pipe, and the velocity and viscosity of the fluids flowing therein. Fowler and Brown, Contamination by Succesive Flow in Pipe Lines, The Petroleus ENGinerR 121 (Aug., 1944). Larger batches reduce the size of percentage contamination. For example, considering a 200 mile line of 8 inch diameter, if 5,000 barrel shipments of gasoline and kerosene are shipped side by side the percentage contamination would be $1.83 \%$, which would probably be enough to increase the flash point of the kerosene beyond state specifications. Cf. Petroleum Rail Shippers' Ass'n v. Alton \& Southern R.R., 243 I.C.C. 589, 657 (1941). However, if the shipments are 25,000 barrels each the percentage contamination would be only $0.3 \%$. See Birge, Contamination Control in Products Pipe Lines, TnE OIL aNd Gas JourNaL 176, 288-91 (Sept. 20, 1947).

159. 243 I.C.C. 589,665 (1941).

160. E.g., Pure Transportation Company Tariff, I.C.C. No. 185, effective January 1, 1954. Some have smaller requirements. E.g., Magnolia Pipe Line Company Tariff, I.C.C. No. A-396, effective October 15, 1953 (10,000 barrels). A few have larger requirements. E.g., Sun Pipe Line Company Tariff, I.C.C. No. 28, effective January 1, 1954 (50,000 barrels). It is possible, however, that products line minimum tenders would have been reduced in any event because of the pooling of information about improved batching techniques during industry operation of the "Little Big Inch" during World War II.

161. E.g., Great Lakes Pipc Line Company Tariff, I.C.C. No. 175, effective December 1, 1953. 
pipe line is often faced with the practical difficulty that, even assuming he has a means of reaching the intake terminal, ${ }^{162}$ he has no place to accumulate his products while awaiting shipment. Likewise, since the pipe line operates continuously and there must be some place for the product to go when delivered at the destination terminal, shippers must also find storage for it there until it can be picked up. Most pipe line tariffs provide that the line will not provide such storage, ${ }^{163}$ and therefore, unless the shipper can afford the cost of constructing his own tanks, he may have to resort to a more expensive form of transportation.

Provisions of the Interstate Commerce Act. A shipper wishing to complain that the failure to provide tankage violates the Interstate Commerce Act apparently can look only to Section 1(4), which obligates all pipe lines to furnish "transportation" upon reasonable request, since other sections are inapplicable or relate solely to railroads. ${ }^{164}$ Moreover, any action should be initiated in a court of law, since the ICC probably does not have jurisdiction to enforce the duty to provide transportation. ${ }^{165}$ "Trans-

162. In many cases a shipper must lease or build terminal facilities, such as dock space, before he can even consider the problem of storage. It was impossible to obtain information on this aspect of the small or spot shipper's difficulty, since it would involve actually visiting each pipe line. Accordingly, the problem will not be discussed.

163. E.g., Detroit Southern Pipe Line Company Tariff, I.C.C. No. 28, effective January 1, 1954; Salt Lake Pipe Line Company Tariff, I.C.C. No. 11, effective December 16, 1953; Wyco Pipe Line Company Tariff, I.C.C. No. 3, effective January 1, 1954. A fëw, however, provide for carrier tankage. E.g., Plantation Pipe Line Company Tariff, I.C.C. No. 16, effective January 1, 1954 (tankage at origin, but not at destination); Pioneer Pipe Line Company Tariff, I.C.C. No. 3, effective January 1, 1954 (tankage at destination, but not at origin). Ordinarily a demurrage charge is levied if the products remain in the tankage beyond a set period. E.g., Great Lakes Pipe Line Company Tariff, I.C.C. No. 175, effective December 1, 1953 (one cent per barrel per day after 30 days).

164. Other sections, although containing language which might be helpful by analogy, are not directly applicable to this specific problem. For example, \$1(21), giving the ICC power to require extension of lines, applies only to railroads. 41 STAT. 478 (1920), as amended, 49 U.S.C. \$1(21) (1946). Section 3(4), which requires installation of interchange facilities, appears to be aimed at discrimination against other carriers only. 24 STAT. 380 (1887), as amended, 49 U.S.C. \$3(4) (1946). Cf. the comparable section dealing with water carriers, which is clearly aimed at discriminations against other water carriers. 54 STAT. 934 (1940), 49 U.S.C. $\$ 905$ (d) (1946). Section 3(5), which provides for the use of joint terminal facilties, applies only to railroads. 24 STAT. 380 (1887), as amended, 49 U.S.C. $\S 3(5)(1946)$. The fact that many sections which would otherwise be applicable to pipe lines are expressly limited to railroads is an indication that there is no duty on pipe lines to provide tankage. In addition, elevation (i.e., grain elevators) is specifically included in the definition of transportation. 41 STAT. 474 (1920), as amended, 49 U.S.C. \$1(3) (a) (1946). Likewise, specific provision is made for stockyards. 24 StAT. 384 (1887), as amended, 49 U.S.C. \$15(5) (1946).

165. United States and ICC v. Pennsylvania R.R., 242 U.S. 208, 222 (1916). In that case, where the ICC sought under \$1(4) to compel the defendant to furnish petroleum tank cars, the Commission relied on $\$ 12$, giving it broad power to enforce and execute the Act, and $\$ 15(1)$, giving it power to regulate "practices." The Court held, however, that the Commission did not have jurisdiction to issue such an order. There is a possibility that since the duty is subject to the limitation that the reguest be reasonable, and since this determination would involve considerable expert knowledge, a court might refuse jurisdiction until the issue had been submitted to the ICC. Cf. Philco Corp. v. American Tel. \& Tel. Co., 80 F. Supp. 397 (E.D. Pa. 1948) (decided with regard to the FCC). See Davis, Anministra- 
portation" is defined in Section 1(3) to include "services in connection with . . . storage." 168 The question is therefore whether terminal tankage falls within that definition, and if so, whether Section 1(4) imposes upon a pipe line an affirmative duty to provide it for all shippers. ${ }^{167}$ There is an unfortunate dearth of precedent on this question, and although pipe lines and railroads are extremely dissimilar in their operation and equipment, ${ }^{108}$ authority can only be found by analogizing cases decided with regard to railroads.

A court would probably adopt the definition of storage which has been established by the ICC in related cases, ${ }^{169}$ that is, storage which is "necessarily incidental" to the transportation of the products. ${ }^{170}$ Therefore, although whether particular facilities are to be considered part of transportation is a question of fact, ${ }^{171}$ tankage already constructed by the pipe lines is probably included. In order to reduce commingling of products within the pipe line, it is necessary to accumulate and ship large batches so that the amount of contamination will be small percentagewise. This necessity and the need for immediate storage at the destination is occasioned by the peculiar nature of the form of transportation itself, not by the practice of shippers. In addition, the pipe lines themselves have prevailed with this same view before the Commission, and such tankage is now included in ICC valuations as property used in carrier operations. ${ }^{172}$

However, inclusion in valuation of voluntarily constructed tankage is different from compelling its construction by a pipe line which has never previously undertaken to provide it. In Railroad Retirement Board $v$. Duquesne Warehouse Co., ${ }^{173}$ where a warehouse company which was wholly owned by a railroad was loading and unloading goods shipped on the railroad, the question was whether the company was an "employer" under the Railroad Retirement Act ${ }^{174}$ and the Railroad Unemployment

TIVE LAw 675 (1951). The ICC apparently still adheres/to the rule of United States v. Pennsylvania R.R., supra. Jacksonville Port Terminal Operators Ass'n v. Alabama, Tennessee \& Northern R.R., 263 I.C.C. 111, 116 (1945). The rule of the case was abrogated with regard to car service by the insertion of $\$ 1(21)$ in 1920. 41 Stat. 478 (1920), as amended, 49 U.S.C. $\$ 1(21)$ (1946). Thus the rule is not changed so far as pipe lines are concerned.

166. 41 Stat. 474 (1920), as amended, 49 U.S.C. $\$ 1$ (3) (a) (Supp. 1952).

167. At least one state has such a requirement in specific terms. LA. REv. Stat. ANN, tit. 45, \$256 (1950).

168. See Minls, The Pipe Line's Place in the Oir Industry $26-9$ (1935).

169. Interpretations by the ICC of the Interstate Commerce Act, though not conclusive, are entitled to great weight. See ICC v. Weldon, 90 F. Supp. 873, 877 (D. Tenn. 1950), aff'd, 188 F.2d 367, cert. denied, 342 U.S. 827 (1951).

170. Atlantic Pipe Line Co., 47 I.C.C. Val. Rep. 541, 546 (1937). Propriety of Operating Practices-New York Warehousing, 216 I.C.C. 291, 349 (1936); Guaranty Claim of the Central Elevator \& Warehouse Co., 72 I.C.C. 169, 176 (1922).

171. See Aron v. Pennsylvania R.R. Co., 80 F.2d 100, 101 (2d Cir. 1935), cert. denied, 298 U.S. 658 (1936).

172. See, e.g., Texas Pipe Line Co., 48 I.C.C. Val. Rep. 249, $250-2$ (1938);

Atlantic Pipe Line Co., 47 I.C.C. Val. Rep. 541, 543-9 (1937).

173. 326 U.S. 446,453 (1946).

174. 50 STAT. 307 (1937), 45 U.S.C. §228(a) (1946). 
Insurance Act. 175 "Employer" is defined in those Acts as one who performs certain services, the services being the same as those embraced in the definition of "transportation" in the Interstate Commerce Act. The Court held that the company was performing a transportation service within the meaning of the Interstate Commerce Act and was therefore an "employer" within the meaning of the other Acts. The Court noted that this was a transportation service even though the duty of unloading carload freight ordinarily rests with the shipper or consignee. Thus the company could not have been compelled by shippers to unload, but since it had undertaken to do so the service became part of the transportation of the goods. ${ }^{176}$ This view is reinforced by the purpose of the broad definition of transportation in Section 1(3), which was to prevent the carrier from making extra, separate charges for facilities used in connection with transportation, but not mentioned in its tariff. ${ }^{177}$ Accordingly, the cases dealing with whether storage is included in transportation have involved only determinations as to charges for, or practices with regard to, existing facilities. ${ }^{178}$

Moreover, a small shipper might need several months to accumulate enough to fulfill his tender and there might be a prolonged delay at the destination terminal until he found or supplied his market. Although this storage may be considered incidental to transportation immediately before and after shipment, it thereafter becomes warehousing, a service which it is neither the pipe line's business nor duty to supply. ${ }^{179}$ On the other hand, if the delay before and after shipment were a short one, the storage might be looked upon as demurrage or ground storage. ${ }^{180}$ A shipper is

175. 52 STAT. 1094 (1938), 45 U.S.C. $\$ 351$ (1946).

176. Cf. Cleveland, Cincinnati, Chicago \& St. Louis Ry. v. Dettlebach, 239 U.S. 588 (1916). In that case, the Court held that a limited liability clause in the bill of lading applied even after the carrier's status had changed to that of warehouseman, since the warehousing service was part of transportation within the meaning of the Act. See American Warehousemen's Ass'n v. Inland Waterways Corp., 188 I.C.C. 13, 15-6 (1932).

177. See Cleveland, Cincinnati, Chicago \& St. Louis Ry. v. Dettlebach, 239 U.S. 588, 594 (1916).

178. E.g., Southern Ry. v. Prescott, 240 U.S. 632 (1916) ; Burkley Produce Co. v. Pennsylvania R.R., 277 I.C.C. 319 (1950).

179. Cf., Propriety of Operating Practices-New York Warehousing, 198 I.C.C. 134, 195 (1933); Reconsignment and Storage of Lumber and Shingles, 27 I.C.C. 451 (1913) ; In re Demurrage Investigation, 19 I.C.C. 496 (1910). See BARNES, INTERstate Transportation 459 (1910); Wolbert, American Pipe Lines 40 (1952).

180. Demurrage is usually thought of as the detention of cars loading and unloading. In order to deter the shippers from using the cars as warehouses, the carrier can assess a demurrage charge after a reasonable time has been allowed for the loading or unloading. This charge is considered to be in the nature of both compensation and a penalty. See Iverson v. United States, 63 F. Supp. 1001, 1005 (D.D.C. 1946) ; Chrysler Corp. v. New York Central R.R., 234 I.C.C. 755, 759 (1939). Demurrage usually occurs on carload shipments, where it is customarily the shipper's duty to load and unload. In the case of less than carload lots, where the carrier customarily undertakes to load and unload, the shipment is usually stored in a freight house belonging to the carrier and demurrage starts to run after a reasonable time. BARNEs, INTERSTATE TRANSPORTATION $\$ 275$ (1910). This storage by the carrier of less than carload lots is ordinarily called "ground storage" to distinguish it from demurrage. 
usually entitled to a reasonable time in which to unload, ${ }^{181}$ and since the pipe line cannot cease its operation, a court might say that it is required to pipe his batch into carrier tankage in order to give him that opportunity. However, there would be no guarantee that the shipper would empty the tank within the reasonable time, or at any time thereafter. Unlike a railroad, which usually provides in its bill of lading that at its option it may store the goods in a public warehouse on expiration of the reasonable time, ${ }^{182}$ a pipe line has no such alternative, since ordinarily there will be no public facilities for storage in the vicinity. Although the rights of the pipe line could be protected by allowing it to sell the products after a set period, this solution would not free the tankage soon enough for other shippers. It is also doubtful whether this principle could be applied to tankage at the origin, since the shipper has ample time in which to accumulate his products for tender. In general, it would seem that attaching the label of demurrage to detention of origin or destination tankage may be misleading. The term implies a duty to provide the tankage, and this duty does not necessarily exist.

Practical Objections. Even assuming that a court would say that terminal tankage is included in a pipe line's duty to provide transportation, that duty is nevertheless subject to the qualification under Section 1(4) that it need be performed only upon reasonable request. Unless there is a drastic change in the structure of the industry, it is doubtful whether there will be any requests for storage which could be considered reasonable.

A carrier is entitled to a reasonable return over its entire operation. ${ }^{183}$ Since most products lines are now operating at a return which is well below the $10 \%$ previously considered reasonable by the ICC, if they were required to construct tankage from which a substantially inadequate return would be realized, their overall return would probably be forced down to such a point as to be confiscatory. This result would not be inevitable, since the increased throughput received from additional shippers would probably lower the operating cost per barrel, ${ }^{184}$ and there is always some

181. See Pennsylvania R.R. v. Kittanning Iron \& Steel Mfg. Co., 253 U.S. 319, 323 (1920); Western Oil \& Fuel Co. v. Great Lakes Pipe Line Co., 210 F.2d 490, 493 (8th Cir. 1954); Terminal Charges at Pacific Coast Ports, 255 I.C.C. 673, 676 (1943); Lake Coal Demurrage, 232 I.C.C. 735, 741 (1939); Peterson, Demurrage, 14 I.C.C. PrAC. J. 526 (1947).

182. UNIForm Bill of Lading $\$ 4(a)$, contained in UnIfordr Freight ClassiFICATIONs filed pursuant to the Interstate Commerce Act. At common law the option was the same. Cf. The Eddy, 5 Wall. 481 (U.S. 1866).

183. Smyth v. Ames, 169 U.S. 466, 526 (1898). See also text at note 217 and note 217 infra.

184. The fixed expenses of a pipe line constitute between $60 \%$ and $70 \%$ of its total operating expenses. Emerson, supra note 136, at 31 . For this reason, its revenue depends almost entirely on throughput, and increases in throughput result in lower cost per barrel-mile. Each pipe line has its own efficiency curve ( $y$ axis= cost per barrel-mile; $x$ axis=throughput), which shows a sharp decline in cost per barrel-mile as throughout increases, until a low point is reached and cost per barrel-mile begins to rise. Most pipe lines operate short of that low point, which represents maximum efficiency, and therefore would welcome an assured increase in throughput. For sample efficiency curves, see Aude, Design and Construction 
leeway within the limits of what a court might consider reasonable. Nevertheless, it seems more likely that newly installed tankage would have to earn close to the same return now received from overall operation, assuming that return to be reasonable, ${ }^{185}$ in order to prevent an unconstitutional confiscation of the pipe line's property.

Although the decision in each case would depend on a business judgment considering all factors, most pipe lines not now operating at ultimate capacity ${ }^{186}$ would be willing to build tankage without a court order if guarantees ${ }^{187}$ by steady shippers would ensure a reasonable overall return. They would do so in order to receive the revenue and to take advantage of any increased efficiency caused by the additional throughput. However, it is doubtful whether such a guarantee is possible under existing conditions. Since there are several different products of varying specifications ${ }^{188}$ which might be shipped, if each small shipper were to insist on preservation of the integrity of his product, ${ }^{180}$ tanks would have to be provided for each

of the Typical Pipe Line System in Common Carrier PIPE Line Operations and Accounting 49, 54 (Graber ed. 1951).

However, small increases may necessitate the installation of additional pumping stations. In that case, there is a sharp increase in fixed costs which is not compensated for until the throughput is further increased. Thus a possible effect of the additional shippers might be an increase, rather than a decrease, in cost per barrelmile. For sample efficiency curves showing the effect on costs of having to install new pumping stations, see $i d$. at 56.

185. The average return of $6.27 \%$ shown in the table above, text at notes $96-101$ supra, for 1951 would clearly seem reasonable in view of the hazards of pipe line operation.

186. A pipe line may be operating at "capacity" with its present number of pumping stations, but by adding additional pumping stations or "loops" in the line (i.e., a short parallel line which by increasing volume for the length of the "loop" increases pressure at its end), it can increase its throughput. However, because of structural limitations in the pipe, or because optimum efficiency has been achieved, there is a point at which it is no longer practicable to add more stations or "loops." If a pipe line is already operating at this point, it would have no interest in handling more shippers.

187. A guarantee could only be accomplished by entering into a long-term contract with a shipper or group of shippers under which the shippers promised to tender a certain number of barrels per year. Even if the shippers would be willing to make such a promise in the first place, there might be difficulty in enforcing it. The only consideration the pipe line can give in return is the promise that it will take the products only if space is available, and the contract might therefore be termed illusory. Any absolute guarantee of large amounts of space by the pipe line would probably be an illegal discrimination under $\$ 3(1)$ of the Interstate Commerce Act, 24 Stat. 380 (1887), as amended, 49 U.S.C. $\$ 3(1)$ (1946). See text at note 191 and note 191 infra.

188. Gasoline can vary in: octane rating, sulphur content, gum content, corrosive acid content, distillation ranges, dye, manufacturing process, and additives (some of which are patented). In contrast, crude oil from the same field usually varies very little. Since crude lines can therefore operate on a "common stream" basis and put different shippers' crude in the same tank indiscriminately, crude lines usually provide carrier tankage.

189. Many small shippers, particularly those shipping lower grade products, probably would not insist on preservation of brand integrity. However, the shipper shipping next to him might, and for that reason the products must be kept separate. There was some evidence at the TNEC hearings which might indicate that gasolines do not vary sufficiently to warrant this treatment. This evidence showed that many companies marketing under brand names had made exchanges of gasoline with other companies also marketing under brand names and distributed the gasoline for consumer use without further processing or blending. TNEC Hear- 
individual and few would constantly be filled to capacity. ${ }^{190}$ In addition to this waste, excess tankage would have to be constructed to accumulate products tendered during peak months and to allow for the instability of demand caused, for example, by independent jobbers who may once in a decade seize the opportunity to buy a large amount of products in a soft market.

It is apparent that these factors would result in huge expenditures of capital on which the pipe line can earn nothing except through terminalling charges. Since products lines historically have been built directly from refineries, in the majority of cases large shippers already have their own refinery tankage near the origin terminal, and their products are pumped into the line from those tanks. Many other large shippers construct their own tankage and operate them at cost in preference to paying terminalling charges which must include the pipe line's profit. Finally, since guarantees of storage when tenders would exceed tankage capacity are probably illegal under Section 3(1) of the Interstate Commerce Act, ${ }^{191}$ many large shippers prefer to build their own tankage in order to have assured space. ${ }^{192}$ The terminalling charges, therefore, cannot be spread out over the pipe line's transportation rate without discriminating against those shippers who use their own tankage. ${ }^{193}$ The cost of excess tankage would have to be borne by the small shipper alone in his payment of terminalling charges, and in contrast to those shippers who have their own tankage, he would also have to pay the pipe line's profit on the operation of the tanks.

Examination of cost figures illustrates the difficulty of compromising the positions of the pipe line and the shipper so that an arrangement would

ings, supra note 9 at 9864-926 (1939). However, present advertising techniques are built on the alleged differences, and most shippers would not be willing to prejudice their advertising by using a "common stream." In addition, gasolines do vary. See note 188 supra.

190. It might be possible for the pipe lines to eliminate some of the excess by building tankage for the use of only those willing to ship common stream, and continue to require that those desiring preservation of their brands construct their own tanks. However, even as to such tankage there would still be the difficulty that the shippers would be unwilling to commit themselves on a permanent or semi-permanent basis, since they would want to reserve the right to choose the cheapest form of transportation for each shipment. For a fuller discussion of the problem of fluctuations due to inconstant demand, see text at note 203 et seq. infra. In addition, it is questionable whether enough shippers would be willing to submit their products to common stream to make this plan feasible.

191. 24 Stat. 380 (1887), as amended, 49 U.S.C. $\$ 3(1)(1946)$. It provides:

"It shall be unlawful for any common carrier . . . to make, give, or cause any undue or unreasonable preference or advantage to any particular person. ..."

192. A shipper may also prefer to have its own tanks, lettered with the brand name, for advertising purposes. Maintaining a private terminal might also serve as an aid in training salesmen, since it can be identified to them as "our own."

193. Because of the prohibition in the Act against discrimination, construction of carrier tankage would lead to scme complicated accounting procedures. Either the tanks would have to be carried on the books as a separate account, the terminalling charges also being kept separate, or, if the tanks were included in the rate base, those shippers owning their own tankage would have to be given an allowance on their rates. Either way, of course, the shipper who did not own his own tankage would be paying more for the storage than those owning their own. 
be satisfactory to both. A 25,000 barrel terminal tank, located reasonably near a large marketing area and including the cost of land, loading racks, and protection equipment would cost about $\$ 50,000$ to construct. 194 If the pipe line built it, the shippers would have to pay in terminalling charges amounts sufficient to cover operating expenses, including maintenance, taxes, and depreciation, and also a $7 \%$ return on valuation. ${ }^{195}$ These amounts would total approximately $\$ 5300$ per year. ${ }^{196}$ If the shipper has an assured demand and would be willing to devote his capital to the tankage, his expenses would be only $\$ 2153$ per year, since he must pay only depreciation, interest on capital, and maintenance. ${ }^{197}$. However, few small

194. This is only a conservative, rough estimate, computed at $\$ 2.00$ per barrel. If only one tank is to be constructed the cost would probably be considerably greater.

195. The figure $7 \%$ was chosen because this Note deals principally with those pipe lines which are subject to the Consent Decree. It is assumed for purposes of this illustration that the line will earn in rates exactly enough to coincide with the 7\% dividend limit set by the Decree. However, in practice the figure might be lower or higher, depending on what a court would allow the pipe line to charge in order to make a reasonable return on its entire operation. See text at note 184 supra.

196. Assuming, as is often the case, that the carrier would finance $50 \%$ of the erection cost, an income statement with regard to the tanks would appear as follows:

Revenues

(This is the amount that would have to be paid in terminalling charges.)

Depreciation

(Computed at $2.71 \%$ per year. This is the usual ICC depreciation rate for tankage.)

Maintenance and General Misc.

(Computed at $1 \%$ of construction cost. See O'BRIEN, Petroleun Tankage and Transmission 71 (1951). Operating expenses, such as payroll and share of office overhead, vary greatly as between single and multiple tank operation. Due to the difficulty of estimating them, for purposes of this hypothetical comparison they are excluded.)

Interest

(Estimated at $2.2 \%$ of the construction cost on a ten year pay-back, ibid. and spread over the 36.9 year life of the tank. This is of course a very rough approximation.)

$\$ 5,300$.

$\$ 1,355$.

500.

Net Taxable Income

149.

State and Federal Income Taxes

(Assumed to be approximately $50 \%$ of net taxable Income.)

Net Income

$\$ 2,004$.

$\$ 3,296$.

$\$ 1,648$.

$\$ 1,648$.

By adding net income and interest, the return on valuation can be determined (i.e., net operating income divided by ICC valuation). Here the total is $\$ 1,797$, or a $7 \%$ return. This was computed as the average of $7 \%$ of the depreciated investment per year, assuming that valuation and depreciated investment coincide.

197. This estimate again excludes operating expenses such as payroll. Assuming that a small shipper would ordinarily finance the entire construction cost, he would therefore have to pay $\$ 298$ in interest charges per year. See note 196 supra. He must also pay $\$ 500$ for maintenance and $\$ 1,355$ depreciation. No effort was made to estimate his filling or standing loss; he would have to bear it in either event, since the carrier would include a loss provision in its tariff. 
shippers would undertake this capital outlay, since they would prefer to shop around for the least expensive form of transportation each time they ship. Furthermore, if the small shipper will use the pipe line only during the peak months in summer and winter, ${ }^{108}$ it will be virtually necessary to set aside a tank for him which he may only turn over three or four times each year. In that case, in order to give the pipe line its return he would have to pay a charge of 7.1 cents ${ }^{199}$ or 5.3 cents ${ }^{200}$ per barrel, respectively. This cost would destroy his competitive position in all areas except those where, as in Greensboro, the saving realized by use of the pipe line instead of a more expensive method of transportation exceeds the amount of the charge.201 Since our larger cities have historically grown up near water, such areas are comparatively few. ${ }^{202}$

Furthermore, a request by a shipper or group of shippers ${ }^{203}$ which would allow the pipe line a return for a single year is not necessarily a reasonable one, since there is no assurance that the tankage would continue to be used in the future if rates of other forms of transportation suddenly decrease. Carrier tankage would probably be used sporadically, depending on rates elsewhere, and those fluctuations would cause decreased efficiency of the pipe line and consequently higher rates. Increased volume necessitates installation of additional facilities, particularly pump stations, and hiring additional personnel. Shutting down and opening up these facilities in accordance with the variation in volume results in extra costs which must ultimately be borne by the consumer. Where, however, the shipper must build his own tankage, his investment will probably make him a steady customer, thus assuring maximum operating efficiency, lower rates, and lower consumer prices. These fluctuations, moreover, often will occur within each year. Demand for gasoline increases sharply during the vacation months of the summer, and there is a similar increase in the demand

198. See text at note 204 infra.

199. I.e., $\frac{\$ 5,300.00}{25,000 \times 3}$
200. I.e., $\frac{\$ 5,300.00}{25,000 \times 4}$

201. In that case, 44.8 cents per barrel. See text at note 152 supra. A pipe line is limited under $\$ 1(5)$ to charges which are just and reasonable, 24 STAT. 379 (1887), as amended, 49 U.S. c. \$1(5) (1946). Nevertheless, it would seem that this section could not be constitutionally applied to limit the pipe line's charges so that it could not maintain a fair return on its overall operation. On the other hand, rates could not be increased to compensate for any reduction in return sustained on account of any such limitation without discriminating against those shippers who own their own tankage. If allowances were given to those shippers who own their own tankage, rates would have to be increased even further, and the small shipper would be no better off than he was before.

202. Westareyer, Economics of Transportation 8 (1952).

203. Such alliances may be rare, since it is often difficult to find shippers going to the same destination at approximately the same time and shipping the same quality product. Compare Prewitt, The Operation and Regulation of Crude Oil and Gasoline Pipe Lines, 56 Q.J. EcoN. 177, 184 (1942) (crude lines). 
for furnace oil during the cold winter months. ${ }^{204}$ In addition, tanker rates may sometimes be cheaper in the summer because of the decrease in demand occasioned by the build-up during those months of storage of furnace oil on the Gulf Coast. Therefore, there would generally be a concentrated demand by small shippers for tankage at these times, ${ }^{205}$ although the time and amount of the demand would, of course, vary according to the section of the country in which the pipe line is located. This sudden concentration not only causes uneconomical operation, but also militates against the possibility that the excess tankage might be used by small shippers during the remainder of the year. Thus, the final conclusion appears to be that no request for tankage is reasonable unless the pipe line can be assured that its use will be uniform and of long duration. Since any shipper who would be in a position to make such a guarantee could operate his own tanks more cheaply, it is unlikely that any such request will ever be made.

A few pipe lines, however, because of their method of operation or location are able to supply tankage for all shippers. For example, the Great Lakes Pipe Line Company undertakes to furnish tankage at destination terminals. ${ }^{206}$ Its ability to do so is undoubtedly derived from the fact that it operates on the "common stream" principle; ${ }^{207}$ that is, it does not attempt to preserve product integrity as between different brands, but only as between different products (e.g., gasoline and kerosene). ${ }^{208}$ Thus it is not necessary to provide separate tanks for all the different brands, as most other pipe lines would have to do. ${ }^{209}$ However, Great Lakes does not furnish tankage at its origin terminals, the probable reason being that most of its lines originate at shipper refineries, and it is uneconomical to provide tankage only for small or spot shippers. On the other hand, The Plantation Pipe Line Company maintains a large tank farm at its origin terminal at Baton Rouge ${ }^{210}$ for the benefit of all shippers. This venture is probably

204. There are also variations in the fall and spring. See Cowles, Transportation in the Oil Industry, 18 ICC PRAC. J. 198, 201-2 (1950).

205. It would seem that the ordinary fluctuations would particularly be heightened in the case of small or spot shippers. Their demand is likely to be highly unstable and probably increases more sharply during peak months than does the demand of large, established shippers.

206. Great Lakes Pipe Line Co. Tariff, I.C.C. No. 175, effective Dec. 1, 1953.

207. Ibid.

208. Other pipe lines include what appear to be "common stream" provisions in their tariffs. E.g., Plantation Pipe Line Company Tariff, I.C.C. No. 16, effective Jan. 1, 1954. However, the provisions are probably inserted only for the protection of the pipe lines, which in fact are fully preserving brand integrity.

209. Great Lakes will perform the services of dyeing and injecting additives into gasoline at destination terminals if the materials are furnished by the shipper, or, if not, for an additional charge. This service necessitates the use of separate tanks, since the gasolines must thereafter be kept separate, and might raise the problems of excess tankage discussed above. However, it is believed that most shippers transport their gasoline to bulk plants before dyeing or injecting additives. In addition, the fact that other products are carried "common stream" and are not changed at the terminal points makes possible savings in tankage as to these products which other pipe lines could not achieve.

210. Plantation also has tank farms at Helena, Alabama, and at Bremen, Georgia. The total capacity of all its tanks is 2,690,000 barrels. Plantation Pipe Line Co., 51 I.C.C. Val. Rep. 782, 789 (1951). 
possible only because of the particular circumstances of the terminal's location. Except for shipments from the huge Esso Standard refinery at Baton Rouge, almost all products delivered at the terminal' come from the Bayou Pipe Line system and the Evangeline Pipe Line system, or by barge on the Mississippi River. Since the Bayou line is smaller than Plantation's, ${ }^{211}$ and since both Bayou and Evangeline operate continuously, products delivered from the Bayou and Evangeline lines must be accumulated at Baton Rouge before being pumped into the Plantation line. Similarly, products delivered by barge must also be accumulated. There being no refineries (other than Esso Standard's) situated near the terminal, all shippers must have tanks constructed there, and the decision as to whether they will build private tankage depends upon the possibility of renting assured space in carrier tanks more cheaply. In this case, since Plantation can count on large and steady shipments to an area not likely to be reached by competitive water transportation, it can afford to provide great amounts of tankage at low charges. ${ }^{212}$ In addition, this arrangement is desirable from the pipe line's viewpoint, since it permits a centralized control and thereby promotes efficiency. However, Plantation does not furnish tankage at destination terminals. It has some nineteen such terminals, ${ }^{213}$ and since it attempts to fully preserve brand integrity, the cost of the necessary tanks at each terminal would be prohibitive.

Analogous Railroad Cases. It is probable that a court would take these economic factors into account in its original determination of whether "transportation" should be construed so as to include a duty to provide tankage. In ICC v. Oregon-Washington R.R. \& Navigation Co., ${ }^{214}$ where the Commission sought to require a railroad to extend its line 185 miles into new territory, the Court, implying that it thought the extension would be unprofitable, held that the power to require extensions given to the Commission in Section 1(21) ${ }^{215}$ would be unconstitutional if construed so as to allow it to impose upon the carrier the burden of entering into new fields of service. A strong dissent ${ }^{216}$ in that case disagreed with the majority's narrow construction of "extension," and pointed out the general rule that a carrier can be forced to perform an unprofitable operation if the system as a whole remains profitable. ${ }^{217}$ However, the dissent's latter

211. Bayou is an 8 inch and 10 inch line, whereas Plantation is a 14 inch and 18 inch line.

212. Plantation makes no separate charge for the use of these tanks except a demurrage charge for detention after 30 days. It therefore must include the cost in its tariff rate. Thus it can be inferred that no shippers own their own tankage, since if they did the inclusion of the tankage charge in the tariff rate would be a discrimination. In addition, it can be inferred that Esso Standard also uses tankage at Plantation's origin and does not pump into the line from refinery tankage.

213. Plantation Pipe Line Co., 51 I.C.C. Val. Rep. 782, 784 (1951).

214. 288 U.S. 14 (1933).

215. 41 Stat. 478 (1920), as amended, 49 U.S.C. $\$ 1(21)$ (1946).

216. By Justices Cardozo, Brandeis, and Stone.

217. This general rule is still good law today. See Alabama Pub. Serv. Comm'n v. Southern Ry., 341 U.S. 341, 352 (1951) (concurring opinion). An exception, inapplicable here, may be made for freight rates. See Comment, 101 U. of PA. L. REv. 1228 (1953). 
proposition does not negative the holding, as applied by analogy to a pipe line, that installation of extensive terminal facilities cannot be compelled, because it is beyond the scope of the line's original undertaking. In City of Los Angeles v. ICC, ${ }^{218}$ where the City of Los Angeles filed a petition for mandamus to compel the ICC to issue an order under Sections $3(3)^{219}$ and $3(4){ }^{220}$ requiring several railroads to build a union terminal, the Court held that the Act did not confer jurisdiction upon the Commission to order such a huge and possibly unremunerative investment by the carriers. Of course, both cases are distinguishable from the instant problem, but they indicate that since there is no express authorization in the Act, a court would probably construe narrowly the pipe line's duty to furnish transportation, so as not to include an obligation to build tankage unless the court could be convinced that the public would benefit and that the cost would not be prohibitive.

Possible Use of Surplus Accumulated under the Consent Decree. If, however, a court should hold that in certain cases terminal tankage must be provided, a possible, but unlikely, solution outside existing law would be to permit in such cases the use of "frozen" ${ }^{221}$ surplus in the construction of additional tankage and to allow the pipe lines to return any profit therefrom to their shipper-owners. Under present conditions, most companies probably would not utilize the surplus to this end, primarily because no return could be expected. At any rate, such a modification of the Decree would probably never be acceptable to the Justice Department, which, in view of its position in the Elkins Act cases that all such dividends and credits are illegal rebates, would consider it an unwarranted deal on a deal. Furthermore, it is questionable whether sufficient amounts have been accumulated by the pipe lines to make any such plan practicable. Only a few lines make these figures public in their required reports, ${ }^{222}$ and this scanty sampling is unhelpful. ${ }^{223}$ However, in view of the lowered level of pipe line rates maintained since 1941, it is highly improbable that there is enough surplus at this time.

\section{CoNCLUSION}

Under decided cases, an interstate products pipe line, although constructed as a private plant facility, may be required to be a common carrier

218. 280 U.S. 52 (1929).

219. Now §3(4). 41 STat. 479, (1920), as amended, 49 U.S.C. \$3(4) (1946).

220. Now §3(5). 41 STAт. 479 (1920), as amended, 49 U.S.C. § 3(5) (1946).

221. I.e., surplus accumulated under the terms of the Consent Decree.

222. The pipe lines sometimes include the amount of accumulation in their Annual Form $P$ Reports. This document is a financial, operating, and statistical report required by the ICC of all carriers subject to its jurisdiction. See Shoemaker, Records and Reports Required by Regulatory Bodies in COMMON CARRIER PIPE IINE Operations and Accounting 159 (Graber ed. 1951).

223. For example, in its 1952 Form $P$ Report Keystone Pipe Line Company showed an accumulation of "frozen" surplus amounting to $\$ 2,511,617$. On the other hand, Pure Transportation Company had accumulated only $\$ 290,560$ and Detroit Southern Pipe Line Company only $\$ 191,548$. 
under the Interstate Commerce Act if it appears to a court that there is sufficient public interest in the line's operation. This public interest will probably be detected if the pipe line enjoys such a significant competitive advantage over other methods of transportation into a particular marketing area that it tends to monopolize the market.

Once having been forced to become a common carrier, or if it voluntarily chooses to become so, the pipe line must publish rates and provide equal transportation for all shippers upon reasonable request. Although many years ago common carrier pipe line rates were at a level which was alleged to be excessive, there has since been a decline of rates under the influence of many factors. These factors include: ICC regulation, stronger competition among the pipe lines and other forms of transportation, congressional investigations, increases in taxes, the threat of pipe line divorcement legislation, improved technology in operation, remedial actions brought by the Justice Department, and the Consent Decree. If pipe line divorcement were desirable, it might be accomplished by prohibiting any return of dividends or credits from pipe lines to their shipper-owners. However, divorcement seems inadvisable, since without the throughput guarantees made possible by integration, independent companies probably could not borrow sufficient capital to construct new lines.

An important obstacle to the use of pipe lines by small or spot shippers is the requirement that they build their own terminal facilities. Although terminal tankage is part of a pipe line's transportation service if the pipe line undertakes to provide it, construction of tankage when the line has never previously furnished it probably cannot be compelled under the Interstate Commerce Act. In addition, construction of tankage for all shippers, except in rare cases where it is justified by the operation or location of the line, would be economically wasteful and could not be accomplished except at prohibitive cost to the pipe line.

A contemporary development has brought products pipe line operation to the forefront in industry thinking and illustrates some of the problems discussed in this Note. After World War II, the Texas Eastern Transmission Corporation purchased the "Little Big Inch" pipe line, a 20 inch line which was built during the war to carry products from the Beaumont, Texas, refinery area to the east coast.224 Texas Eastern has used the line to transport natural gas since 1947, but now plans to reconvert it as far east as Moundsville, West Virginia, to carry petroleum products. $^{225}$ The line traverses Louisiana and Arkansas, crosses the Mis-

224. Just prior to World War II, it had been expected that the oil companies would construct and operate a large transcontinental pipe line to provide transportation to the east coast in the event of war. However, they were unable to get the necessary allocation of steel before Pearl Harbor, and the operation of the German submarine fleet thereafter caused the companies to suffer such great losses that they were unable to build it with private funds. The "Big Inch" and "Little Big Inch" pipe lines were therefore constructed with Government funds under the auspices of the War Emergency Pipe Lines, a nonprofit agency staffed with members of the industry.

225. Annual Report for 1953, Texas Eastern Transmission Corp. 16 (1954). 
sissippi River at Cape Girardeau, Missouri, and runs through the southern part of Illinois, Indiana, and Ohio. The "Little Big Inch" would be the first common carrier products line to cross the entire country, and because of its huge size ${ }^{226}$ its rates will be relatively low. If the project is carried out, ${ }^{227}$ the effect upon present methods of transportation to marketing areas in the Mississippi and Ohio River valleys will be significant. Barge traffic on the Mississippi River will be substantially affected, ${ }^{228}$ and pipe lines now running westward from the east coast may lose some of their throughput. Conversion of the pipe line will be possible without throughput guarantees, principally because of the well established credit of Texas Eastern. In addition, the property has been depreciated far below reproduction cost, and investors realize that it will be many years before a competing method of transportation can achieve an equal footing. The line will attempt to fully maintain brand integrity and will have many origin and destination terminals. As a consequence, it plans to own no terminal tankage except, perhaps, at Cape Girardeau on the Mississippi River and at Moundsville on the Ohio River, if further study indicates operating and economic feasibility of such tankage. The pipe line thus illustrates: the hazards of competition faced by pipe lines; the particular circumstances under which construction of pipe lines without throughput guarantees may be possible; and the economic undesirability of furnishing tankage for shippers.

226. The "Little Inch" carried 235,000 barrels of products per day during the latter part of World War II. See Petroleum 65 (Am. Pet. Inst. ed. 1949).

227. The line may not be withdrawn from natural gas service without the prior approval of the Federal Power Commission. 15 U.S.C. \$717f(b) (1946).

28. The sentiment of the barge operators in this regard is illustrated by a complaint filed recently by three corporations operating barges on the Mississippi and Ohio Rivers. The complaint charges that the conversion of the "Little Inch" by Texas Eastern will violate Sections 1 and 2 of the Sherman Act and alleges that the conversion will financially ruin the plaintiffs. Complaint, River Company, Inc. v. Texas Eastern Transmission Corp., Civil No. 93/209, S.D.N.Y., May 21, 1954. 